\title{
THE WESTERN BALKANS: WEAK PERFORMANCE SINCE THE CRISIS*
}

\author{
Marek DABROWSKI - Yana MYACHENKOVA
}

In the early and mid-2000s, the prospect of EU accession and the global boom facilitated rapid economic recovery and boosted economic and institutional reforms in the Western Balkan region. The global financial crisis of 2007-2009 and the European crisis of 2010-2013 slowed the pace of economic growth and amplified high unemployment in the region. In addition, various unresolved legacies from past conflicts slowed the pace of reform and progress towards EU accession.

The European Commission's February 2018 communication sets an indicative deadline (2025) for the two most advanced candidates - Serbia's and Montenegro's admission to the EU. This could incentivise all Western Balkan countries, including those candidates that have not yet started membership negotiations (Macedonia and Albania) and those waiting for candidate status (Bosnia and Herzegovina and Kosovo), to remove domestic political obstacles to EU accession, solve conflicts with neighbours, speed up reforms and accelerate economic growth.

Keywords: Western Balkans, global financial crisis, European Union, EU accession, economic integration, economic reforms, institutional reforms

JEL classification indices: E42, F15, F16, F21, F24, F32, F35, F51, H62, H63, I32, J64

* This is a substantially expanded, revised and updated version of our paper published in the Bruegel Policy Contribution in 2018. The authors would like to thank Alexander Lehmann, J. Scott Marcus, André Sapir, Ben Slay, Alessio Terzi, Nicolas Véron, Guntram Wolff and Georg Zachmann for their comments on an earlier version of this paper. However, authors assume the full responsibility for its content. Opinions presented in this paper can be attributed solely to authors and not necessarily to institutions, which they are affiliated to.

Marek Dabrowski, corresponding author. Fellow at Bruegel, Brussels; Professor at the Higher School of Economics, Moscow; Co-founder and Fellow at CASE - Center for Social and Economic Research, Warsaw. E-mail: Marek.Dabrowski@case-research.eu

Yana Myachenkova, Research Assistant at Bruegel, Brussels.

E-mail: yanamyachenkova@gmail.com 


\section{INTRODUCTION}

The Western Balkans is a geopolitical term coined by the governing bodies of the European Union (EU) in the early 2000s and referring to those countries in south-eastern Europe that were not EU members or candidates at the time but could aspire to join the bloc. Originally, the Western Balkan region consisted of seven countries - Albania, Bosnia and Herzegovina, Croatia, Kosovo, Macedonia $^{1}$, Montenegro and Serbia - but Croatia has already joined the EU.

In the 1990s, the region suffered from severe conflicts that had negative political and economic consequences that continue to be felt. In the early and mid2000 s, the prospect of EU accession and the global boom facilitated rapid economic recovery and boosted economic and institutional reforms in the region. However, the global financial crisis of 2007-2009 and the subsequent European financial crisis of 2010-2013 (that affected in particular the southern flank of the EU) slowed down the pace of economic growth in the region and amplified high unemployment, especially among young people. In addition, various unresolved legacies from past conflicts slowed the pace of reform and progress towards EU accession in Western Balkan counties and intensified nationalist sentiments across the region.

Given its geographical location, the region is important to the EU in terms of security, stability, trade and transit routes. Therefore, the Western Balkan countries' economic and political prospects and their future within a European framework should remain one of the top priorities for the EU.

This paper concentrates on economic and social development in the region before, during and after the global financial crisis. Naturally, we also take political and geopolitical factors into consideration but as the background rather than central theme of our analysis. We conclude with broad recommendations pertinent to the EU accession of Western Balkan countries. Our paper consists of seven sections. Section 2 presents historical, geographical and geopolitical background of our analysis. Section 3 is devoted to macroeconomic and social performance since the beginning of the current century. In Section 4, we analyse trade, investment, migration and official aid flows with special attention given to the role of the EU. Section 5 discusses major institutional and governance challenges faced by the Western Balkan countries. In Section 6, we present the updated overview of the EU accession process. Finally, Section 7 contains policy conclusions and

1 Because of the conflict with Greece over the country's official name (see sections 2 and 6), international organisations and the EU use the temporary name 'the Former Yugoslav Republic of Macedonia' (FYROM) - see Section 2. However, for the sake of editorial simplicity, we use the short name 'Macedonia'. 
recommendations. The dominant analytical framework and methodology consist of an analytic narrative supported by a cross-country statistical comparison based on the available statistical databases of the IMF, WB, UNCTAD, UNECE, EBRD and those presented in other publications cited in this paper. Unfortunately, data for Kosovo remains incomplete.

\section{CONFLICT LEGACIES AND GEOPOLITICS}

Between 1918 and 1991, all Western Balkan countries except Albania were part of Yugoslavia. After World War II, similarly to most of their Central and Eastern European neighbours, the countries were under communist rule. However, in 1948 Yugoslavia split with the Soviet Union and remained independent from major geopolitical and military blocs in Europe, becoming one of the founders of the Non-Aligned Movement. After 1950, Yugoslavia developed a unique decentralised market socialism model based on employee-managed firms. Although this did not protect the country from macroeconomic disequilibria (repeated episodes of high inflation and hyperinflation, large external debt and high unemployment), it allowed the creation of quasi-market institutions and market-oriented microeconomic behaviour. Unlike countries of the Soviet bloc, Yugoslavia remained relatively open to the world in terms of trade and its citizens' freedom to travel. By contrast, Albania, which also split with the Soviet Union in 1962, chose an orthodox model of a centrally planned economy based on national self-sufficiency and closed to the outside world.

When Yugoslavia began to collapse in 1991, most of its successor states suffered from violent ethnic conflicts, which negatively affected the entire region in terms of war damage, human suffering, disrupted trade links, refugee flows, sanctions, organised crime and so on. In the 1991-2001 decade, the conflicts resulted in the death of an estimated 130-140 thousand people. The bloodiest wars in Croatia, Bosnia and Herzegovina and Kosovo produced almost 4 million displaced persons (ICTJ 2009). This series of civil wars was stopped only by the intervention of United Nations and NATO forces and the EU's generous promise to allow countries in the region to apply for EU membership once they re-establish peace and meet the accession criteria. However, the legacies of past conflicts continue to overshadow the regional and pan-European politics until today:

- Serbia, five EU member states (Cyprus, Greece, Romania, Slovakia and Spain) and several other countries ${ }^{2}$ do not recognise Kosovo as an independent state.

Including Argentina, Brazil, Chile, China, India, Indonesia, Iran, Israel, Nigeria, Russia, South Africa, Ukraine and most countries of the former Soviet Union. 
Internally, tensions between various ethnic groups in Kosovo (Albanian, Serbian, Roma and Turks) have not been resolved and occasionally they even intensify (see RFE/RL 2018) following, among others, turbulences in relations between Serbia and Kosovo 3 . Domestic stability of Kosovo continues to rely on international peacekeeping forces and supervision of the United Nations Interim Administrative Mission in Kosovo (UNMIK).

- Bosnia and Herzegovina, where the civil war was brought to an end by the Dayton Agreement in 1995, is a very loose two-tier confederation of three ethnic communities that is hardly manageable at the central level (ICG 2012; Suljagic 2018). Politics in these entities continues to be dominated by nationalist sentiments. As a result, the international community must continue its peacekeeping mission and state-building support more than 20 years after the end of the war.

- Greece disputes Macedonia's country name ${ }^{4}$ and this conflict has frozen the country's EU and NATO accession process for more than a decade. The agreement of 17 June 2018 between Greece and Macedonia, according to which the latter accepted the new name of the Republic of North Macedonia, opened a way to unblock both accessions. But both countries now face a lengthy and politically complicated ratification process, including adoption of the respective changes into the Macedonian constitution (Fouere 2018). Internally, Macedonia has suffered periodically from ethnic tensions between its own majority and the Albanian minority. Furthermore, the 10-year term of former Prime Minister Nikola Gruevski (1996-2006) was marred by numerous violations of the rule of law and political and civil liberties.

- Apart from Macedonia, some authoritarian backsliding has been noted since 2015 in Serbia, Montenegro and Bosnia and Herzegovina (Bechev 2018). This is seen, among others, in their deteriorating Freedom House's ratings ${ }^{5}$. In the 2018 Freedom in the World surveys, all Western Balkan countries except Serbia were rated as "partly free". Though Serbia retained a "free" status, it is on the verge of downgrading to "partly free" category. Similarly, The Economist Intelligence Unit's 2017 Democracy Index ranks Serbia $66^{\text {th }}$ out of 167 countries and territories as the "flawed democracy". Other Western Balkan Countries are rated as "hybrid regimes" - Albania on $77^{\text {th }}$ position, Montenegro $-83^{\text {rd }}$, Macedonia $-88^{\text {th }}$ and Bosnia and Herzegovina $-101^{\text {st }}$ (EIU 2018, chapter 3 ).

3 Overall, tensions between Serbia and Kosovo have been partly mitigated in recent years thanks to active EU diplomacy and incentives created by the prospect of EU membership.

4 Macedonia is the name of Greece's northern region. Greece also questions the right of Macedonia to refer to the historical memory of Alexander the Great (Gligorov 2018).

https://freedomhouse.org/sites/default/files/Country\%20and\%20Territory\%20Ratings\%20 and\%20Statuses\%20FIW1973-2018.xlsx 
- All countries in the region face problems with corruption (see Section 5) and organised crime. The roots of the latter can be tracked back, at least partly, to the conflicts of 1990s and the resulting UN sanctions.

All the above-mentioned legacies of past conflicts and problems with building stable democracies contribute to the slow pace of the EU accession process in the region. In addition, EU members' appetites for further enlargement have been reduced by the financial crisis years (2007-2013) and associated social and political tensions, the wave of Euro-scepticism and nationalism and also Brexit.

However, there are signs of a changing atmosphere. (i) In his State of the Union address on 13 September 20176, European Commission (EC) President Jean-Claude Juncker recognised the strategic importance of further enlargement once the candidate countries meet the accession criteria. (ii) The new enhanced Western Balkan strategy elaborated by the EC (2018a) sets 2025 as a possible time horizon for Montenegrin and Serbian accession. (iii) The EU - Western Balkans Summit in Sofia on 17 May 2018 confirmed the EU's "unequivocal support" for the European perspectives of the region and outlined priorities of the EU accession process and intra-regional cooperation. They include, among others, acceleration of judicial reforms, extending rule of law advisory and peer-review missions, expanding the Western Balkans Investment Framework and EU Energy Union, building regional electricity market, digital infrastructure, etc. (European Council 2018).

These are good news, because the slow pace of the accession process and the lack of enthusiasm among current EU members to accept new entrants might weaken incentives for further reforms in the Western Balkan countries, reverse those already in place and derail the enlargement process, as already happened partly with Turkey. In turn, this could mean a serious risk of a new round of intra-regional conflicts and geopolitical destabilisation in the EU's closest neighbourhood.

Faced by such risks, the EU and its member states must not overlook the strategic importance of the Western Balkan region. Geographically, the Western Balkan countries form a land bridge and the shortest transit route between the southeast flank of the EU (Greece, Bulgaria and Romania) and its central European 'core' (Hungary, Croatia, Slovenia and Austria). The importance of this transit area was demonstrated during the 2015-2016 refugee crisis. The close cooperation between the Western Balkan governments and the EU played a major role in closing the Balkan route to refugee flows. Because of its geographical location and long and complicated land borders with its Western Balkan neighbours,

6 http://europa.eu/rapid/press-release_SPEECH-17-3165_en.pdf. 
Croatia could be the major beneficiary of further enlargement ${ }^{7}$. Economically, the EU is the largest partner of the Western Balkan countries (Section 4).

The geopolitical vacuum created by the delayed prospect of EU membership and decreasing EU's interest in the region could also encourage other players, such as Russia and China (Fouere 2017) to become more active. To a limited extent, this has already happened. China finances an increasing number of infrastructure projects throughout Central and Eastern Europe, including Western Balkans (Kynge - Peel 2017; Byrne - Mitchell 2017). Russia's engagement in the region concentrates on geopolitical goals. In particular, Russia wants to discourage the Western Balkan countries from joining $\mathrm{NATO}^{8}$ and is not enthusiastic about their EU membership bids. Serbia is a major target for Russian efforts because of the historical and cultural links between the two countries (Hartwell - Sidlo 2017). However, Serbia has been reluctant to take any step that would damage its EU accession prospects and openly distance it from the mainstream EU foreign policy. The exception in this respect is its refusal to join EU sanctions against Russia (in retaliation for the annexation of Crimea and Russia's involvement in the Donbass conflict). Beyond Serbia, there was some evidence of Russia's involvement in the failed coup plot in Montenegro in October 2016, which was seen by the ruling Democratic Party of Socialists as an attempt to stop Montenegro's accession to NATO (Hopkins 2017). Turkey, another historical player in the region, is active in the economic and cultural sphere, especially in Albania, Kosovo and Bosnia and Herzegovina. It also has the ambition to play an active peace-building role in the region (Bechev 2012).

\section{MACROECONOMIC AND SOCIAL PERFORMANCE}

This section presents an analysis of the macroeconomic and social performance of the Western Balkan region, paying particular attention to the pace of its catching up with the German and the EU's average income levels.

\subsection{Income per capita}

In 2016, all Western Balkan countries except Kosovo were classified as upper middle-income countries according to the World Bank Atlas method. This cat-

7 For example, the only road connection between its southern and central parts (the Adriatic highway) goes through the territory of Bosnia and Herzegovina, which is an obstacle to Croatia joining the Schengen area.

8 So far two countries of the region joined the NATO: Albania (2009) and Montenegro (2017). 


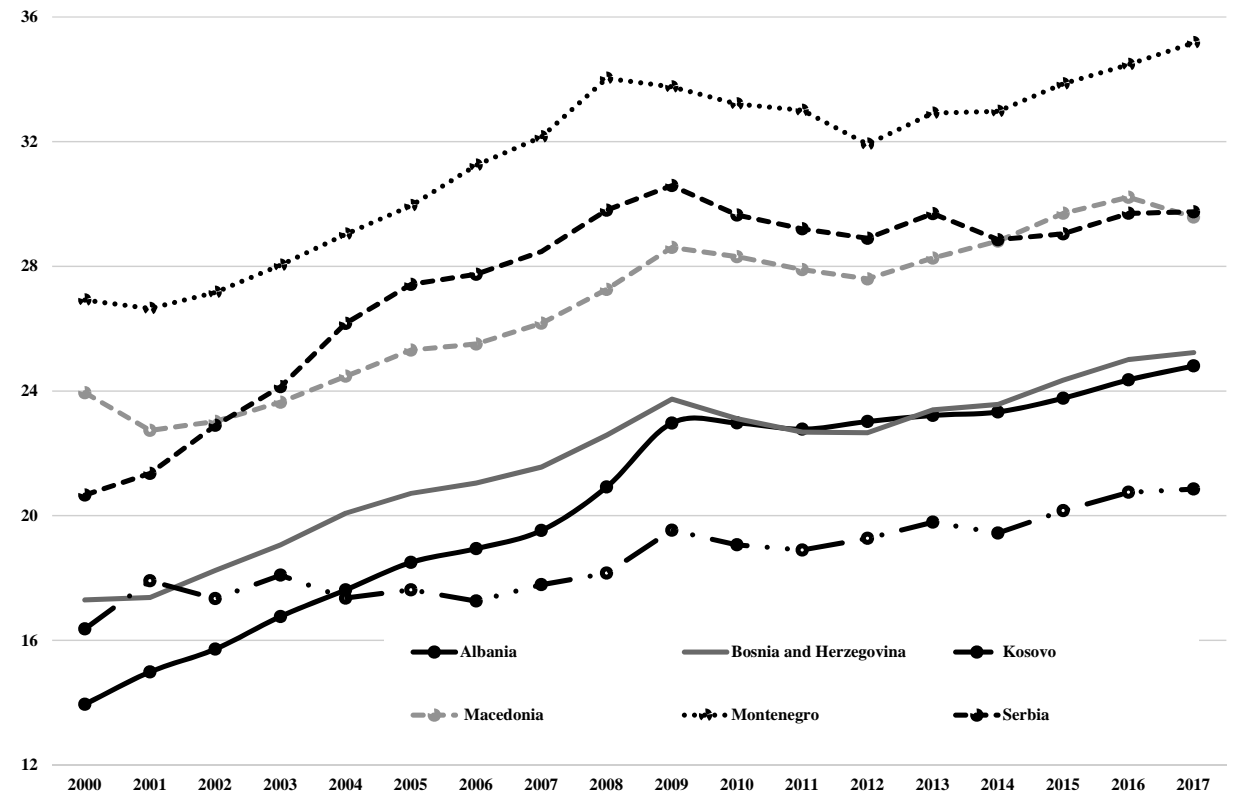

Figure 1. GDP per capita in current international \$, PPP adjusted, Germany $=100 \%, 2000-2017$

Source: World Economic Outlook database, April 2018.

Note: IMF staff estimates for Kosovo (the entire period), Albania (2012-2017) and all countries except Germany (2017).

egory includes countries with gross national income (GNI) per capita between $\$ 3,956$ and $\$ 12,235$. However, most Western Balkan countries are towards the bottom of this income group - between $\$ 4,180$ in Albania and \$5,310 in Serbia. Even Montenegro with the region's highest GNI per capita $(\$ 7,120)$ recorded approximately only one sixth of German and one fifth of EU's average GNI per capita. Kosovo, the region's poorest country with GNI per capita of $\$ 3,850$, belongs to a lower middle-income economy group.

Nevertheless, since 2000 the Western Balkan region has seen income per-capita convergence towards Western European levels, represented in our analysis by Germany ${ }^{9}$ (Figure 1).

The income convergence process was particularly strong between 2000 and 2009 , on the background of rapid economic growth in the region (Figure 2) and

We chose Germany as a benchmark because of its roles as the largest EU national economy and as a major economic and trade partner of Western Balkan economies. Germany also had a largely positive but rather modest rate of growth in the 2000s and 2010s. 
the global economic boom. The gap in income per-capita levels in purchasing power parity (PPP) between Serbia and Germany narrowed by 9.9 percentage points and between Albania and Germany by 9.1 percentage points. Other countries converged at a slower pace - Montenegro by 6.9 percentage points, Bosnia and Herzegovina by 6.4 percentage points, Macedonia by 4.7 percentage points and Kosovo by only 3.1 percentage points. After 2010, the convergence process slowed down due to the spillover effects of the global and European financial crises. The 2010-2012 period brought even de-convergence, compared to the relative income per capita level of 2009. Since 2012-2013, convergence has restarted but at a slower pace than in the 2000s. By 2017, Serbia had still not managed to regain its relative income per capita level (as compared to Germany) of 2009.

Overall, between 2000 and 2017 Albania saw the biggest progress in income per capita convergence (by 10.9 percentage points) followed by Serbia (9.0 percentage points), Montenegro (8.3 percentage points), Bosnia and Herzegovina ( 7.9 percentage points), Macedonia (5.7 percentage points) and Kosovo (4.5 percentage points). The political and geopolitical factors discussed in section 2 have had at least partial impacts on the observed differences in the pace of convergence.

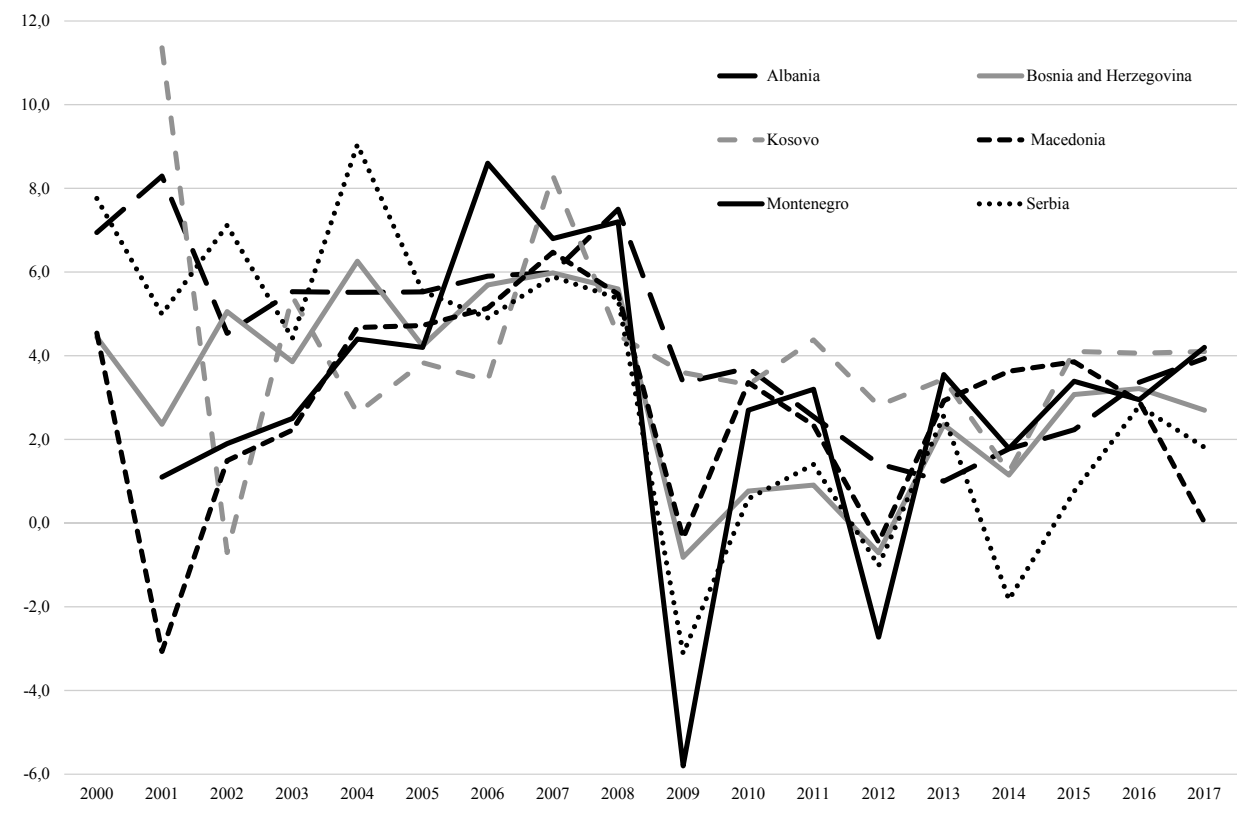

Figure 2. Real GDP growth, annual per cent change, 2000-2017

Source: World Economic Outlook database, April 2018. 


\subsection{Social challenges}

Despite progress in income convergence, the Western Balkan region continues to face social risks associated with poverty, income inequality, unemployment, especially among young people, and other forms of social exclusion.

Table 1 shows that there has been some progress in the Western Balkans in reducing poverty gaps $^{10}$ at $\$ 1.90, \$ 3.20$ and $\$ 5.50$ a day (in 2011 PPP) since 2001. For Macedonia, the proportion of people living below the thresholds of $\$ 1.90$ and $\$ 3.20$ almost halved after 2010. Substantial reductions in the percentage of people living below the thresholds of $\$ 3.20$ and $\$ 5.50$ a day were also accomplished in Kosovo (2013 compared to 2005). In Serbia, the percentage of people living below all three thresholds was largely unchanged between 2002 and 2013. In Montenegro, there was even some deterioration for the highest threshold, probably as a result of the global and European financial crises. However, in both Serbia and Montenegro, poverty figures remain low compared to their Western Balkan neighbours.

Table 1. Poverty gap at $\$ 1.90, \$ 3.20$ and $\$ 5.50$ a day (2011 PPP), $\%$

\begin{tabular}{l|c|r|r|r|r|r|r|r|r}
\hline Poverty gap at $\rightarrow$ & \multicolumn{3}{|c|}{$\$ 1.90$ a day } & \multicolumn{3}{c|}{$\$ 3.20$ a day } & \multicolumn{3}{c}{$\$ 5.50$ a day } \\
\hline Country $\downarrow$ & 2005 & 2010 & 2013 & 2005 & 2010 & 2013 & 2005 & 2010 & 2013 \\
\hline Albania & 0.2 & $0.1^{\mathrm{b}}$ & $0.2^{\mathrm{d}}$ & 2.2 & $1.1^{\mathrm{b}}$ & $1.6^{\mathrm{d}}$ & 12.4 & $9.0^{\mathrm{b}}$ & $10.3^{\mathrm{d}}$ \\
\hline Bosnia and Herzegovina & $0.1^{\mathrm{a}}$ & $0.0^{\mathrm{c}}$ & & $0.2^{\mathrm{a}}$ & $0.1^{\mathrm{c}}$ & & $1.0^{\mathrm{a}}$ & $0.8^{\mathrm{c}}$ & \\
\hline Macedonia & & 4.3 & 3.5 & & 8.0 & 6.5 & & 15.9 & 13.0 \\
\hline Kosovo & 0.6 & 0.3 & 0.2 & 4.2 & 2.8 & 0.9 & 17.7 & 13.9 & 5.8 \\
\hline Montenegro & 0.1 & 0.0 & 0.2 & 0.3 & 0.1 & 0.9 & 2.1 & 0.8 & 2.4 \\
\hline Serbia & 0.3 & 0.0 & 0.0 & 1.1 & 0.3 & 0.3 & 5.0 & 2.1 & 2.0 \\
\hline
\end{tabular}

Source: World Bank's World Development Indicators.

Notes: $\mathrm{a}=2004, \mathrm{~b}=2008, \mathrm{c}=2011, \mathrm{~d}=2012$. See footnote 10 for poverty gap definition.

In terms of income inequality, the region does not differ from the rest of Europe, i.e. its Gini index represents a moderate level. The exception was Macedonia in 2010, where a high Gini index of 42.8 was recorded (Figure 3), but it declined to 28.5 in 2013. Changes in the Gini index in the region have not followed a single trend: it has remained broadly stable in Albania and Bosnia and Herzegovina, but has fluctuated somewhat in other countries. World Bank (2017) attributes these trends to problems with job creation prior to 2009 , combined with

10 Poverty gap is defined as the mean shortfall in income or consumption from the respective poverty line (counting the non-poor as having a zero shortfall), expressed as a percentage of that poverty line. 


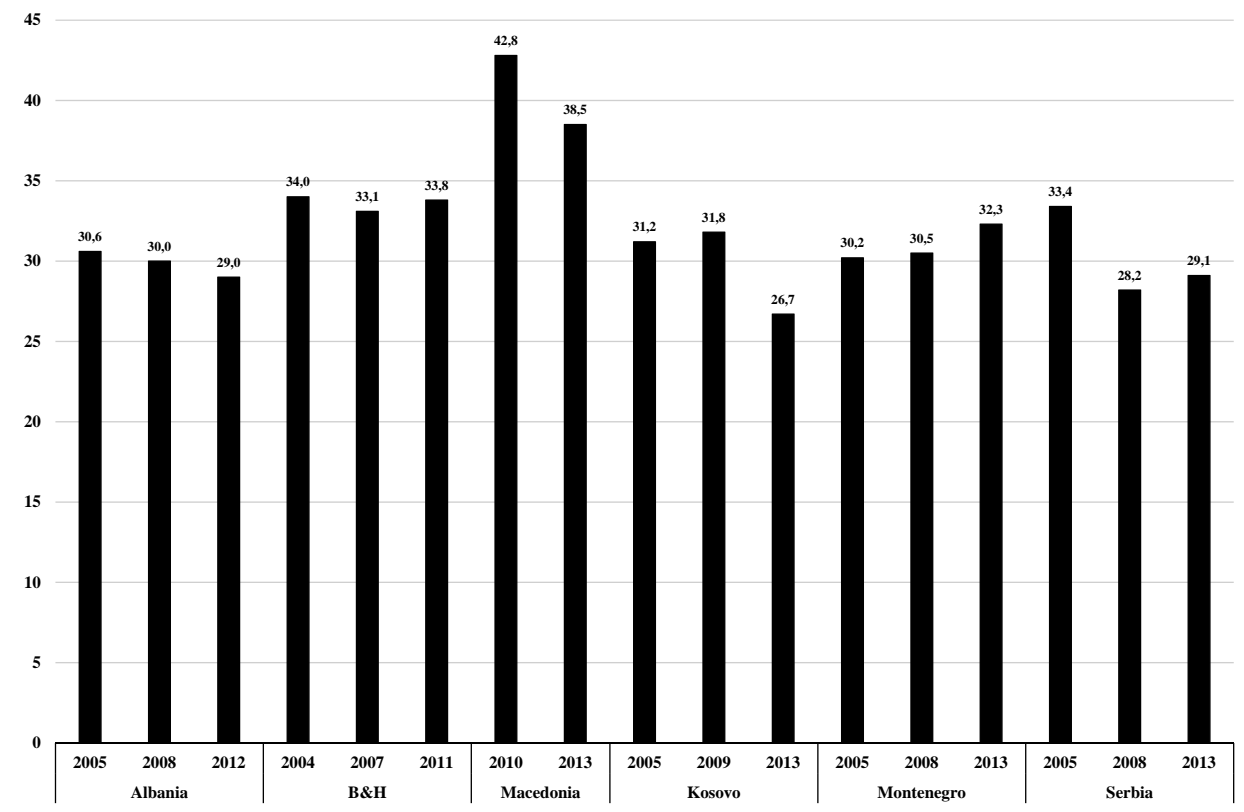

Figure 3. Western Balkans, Gini indices, 2004-2013

Source: World Bank World Development Indicators.

low productivity in most sectors. This points to the inefficiency of labour market institutions, one of the legacies of employee self-management in the former Yugoslavia (Roaf et al. 2014). As a result the region has been always characterised by very high unemployment rates, even before the transition started.

Figure 4 shows that in 2001, the unemployment rate in Kosovo approached $60 \%$ of the labour force. Since then, Kosovo's labour market had improved: its unemployment rate in 2016 was only half the 2001 level, but still close to $30 \%$. Macedonia has been the second-highest unemployment country in the Western Balkan region, with the unemployment rate exceeding 30\% of labour force during most of the examined period and decreasing only recently. Bosnia and Herzegovina has seen very slow improvements in its unemployment rate since 2006 and had a similar level of unemployment as Kosovo and Macedonia in 2016.

Albania has been the best performing country in this respect (perhaps thanks to the absence of the legacy of the Yugoslav employee self-management model), with an average unemployment rate equal to approximately $15 \%$ of the labour force. One might argue that high unemployment results from the informal labour market, which is in turn driven by high taxes and regulatory barriers (Section 5). Based on Business Environment and Enterprise Performance Survey data, sev- 


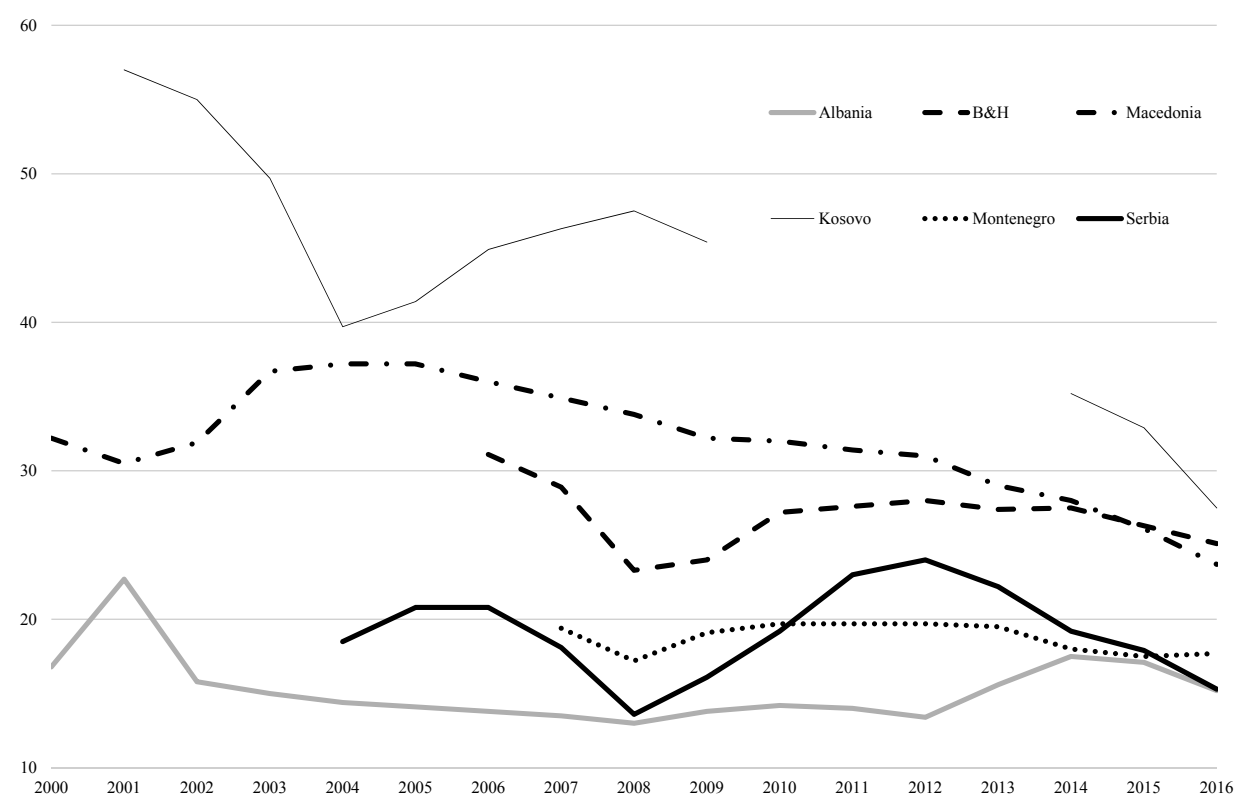

Figure 4. Unemployment, \% of total labour force, 2000-2017

Source: World Bank World Development Indicators.

Note: Estimates.

eral studies (e.g. Koettl-Brodmann et al. 2017) conclude that barriers to entry for new firms and other regulatory impediments contribute to high unemployment in the region.

Table 2 shows unemployment rates per educational level. It is notable that better education has not increased the likelihood of being employed in the Western Balkans (unlike in Germany, which serves as a benchmark) except for the very recent period (2016), when the unemployment rate for people with advanced education markedly declined in Bosnia and Herzegovina and Kosovo. In Albania, the unemployment rate of people with basic education is systematically lower than the rate for those with intermediate and advanced education levels. These findings might suggest a substantial role of the informal labour market (regardless of education level) and a mismatch between education profile and quality and actual demand for labour.

The region also suffers from very high youth unemployment rates (Figure 5), which significantly exceed the overall unemployment rates (Figure 4). The highest youth unemployment rates are recorded in Kosovo and Bosnia and Herzegovina, while Montenegro and Serbia have the lowest. However, even the Serbian and Montenegrin rates (the lowest in the region in 2016) are about five times 
Table 2. Unemployment rates for people with basic, intermediate and advanced education (\% of total labour force in respective education group)

\begin{tabular}{l|c|c|c|c|c|c|c|c|c|c|c}
\hline Country & 2006 & 2007 & 2008 & 2009 & 2010 & 2011 & 2012 & 2013 & 2014 & 2015 & 2016 \\
\hline Basic & & & & & & & & & & & \\
\hline Albania & & & 10.5 & 12.4 & 13.8 & 10.4 & 8.4 & 10.3 & 10.8 & 11.5 & \\
\hline $\begin{array}{l}\text { Bosnia and } \\
\text { Herzegovina }\end{array}$ & & & & & & & & & 35.0 & & 9.1 \\
\hline Kosovo & & & & & & & & & 49.0 & 39.5 & 47.6 \\
\hline Macedonia & 43.3 & 42.7 & 40.5 & 40.0 & 36.6 & 33.3 & 31.3 & 31.2 & 29.9 & 26.3 & 26.1 \\
\hline Montenegro & & & & & & 31.3 & 35.0 & & & & \\
\hline Serbia & & & & 20.8 & 26.9 & 29.7 & 30.9 & 27.6 & 22.5 & 19.4 & 14.9 \\
\hline Germany & 17.5 & 15.9 & 14.2 & 13.8 & 12.8 & 11.7 & 10.9 & 10.1 & 9.9 & 9.5 & 8.7 \\
\hline Intermediate & & & & & & & & & & & \\
\hline Albania & & & 18.6 & 19.6 & 19.7 & 17.5 & 13.2 & 17.0 & 20.7 & 22.9 & \\
\hline Bosnia and & & & & & & & & & 33.9 & 35.0 & 7.9 \\
\hline Herzegovina & & & & & & & & & & & \\
\hline Kosovo & & & & & & & & & 45.2 & 41.1 & 36.7 \\
\hline Macedonia & 38.4 & 36.3 & 34.1 & 32.6 & 33.4 & 31.8 & 31.9 & 28.9 & 29.8 & 25.9 & 22.7 \\
\hline Montenegro & & & & & & 20.5 & 21.7 & & & & \\
\hline Serbia & & & & 19.4 & 22.0 & 25.5 & 26.5 & 26.1 & 21.8 & 20.5 & 18.3 \\
\hline Germany & 9.6 & 8.2 & 7.2 & 7.0 & 6.2 & 5.3 & 4.9 & 4.7 & 4.2 & 3.8 & 3.3 \\
\hline Advanced & & & & & & & & & & & \\
\hline Albania & & & 15.4 & 18.5 & 14.4 & 18.7 & 19.2 & 16.2 & 18.2 & 21.5 & \\
\hline Bosnia and & & & & & & & & & 22.2 & 20.9 & 11.6 \\
\hline Herzegovina & & & & & & & & & 27.2 & 28.0 & 8.2 \\
\hline Kosovo & & & & & & & & & 27.1 & 22.5 & 21.0 \\
\hline Macedonia & 22.9 & 23.2 & 23.7 & 24.8 & 24.8 & 26.3 & 26.0 & 26.7 & 24.6 & 22.9 & \\
\hline Montenegro & & & & & & 13.9 & 11.6 & & & & 14.8 \\
\hline Serbia & & & & 10.7 & 12.9 & 16.0 & 17.9 & 18.8 & 16.8 & 17.0 & 2.5 \\
\hline Germany & 5.3 & 4.5 & 3.9 & 3.7 & 3.2 & 2.7 & 2.6 & 2.6 & 2.8 & 2.5 & 2.3 \\
\hline
\end{tabular}

Source: World Bank World Development Indicators.

and twice as high as in Germany and the EU, respectively. Lack of employment opportunities for young people creates incentives for them to emigrate to more developed countries with better functioning labour markets and more job opportunities.

Emigration adds to the already unfavourable demographic trends in the region (see Section 4). The Western Balkan population is shrinking and aging. The median age of the Western Balkans region is 8.7 years above the world average and is expected to increase in the future (World Bank 2017).

Figure 6 shows that the birth rate has decreased by approximately three births per 1000 people on average in the region from 2000 to 2015. The largest decreases in the numbers of births have been recorded in Kosovo, Albania and Montenegro. 


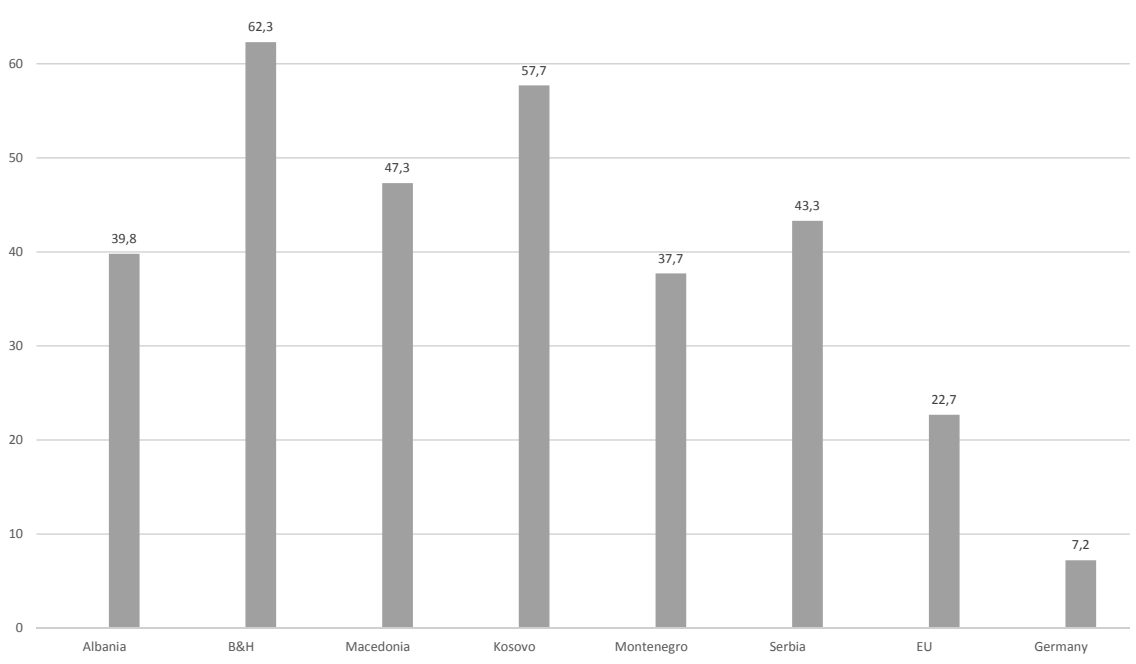

Figure 5. Youth unemployment, \% of labour force aged 15-24, 2015

Source: World Bank World Development Indicators.

Note: Estimates.

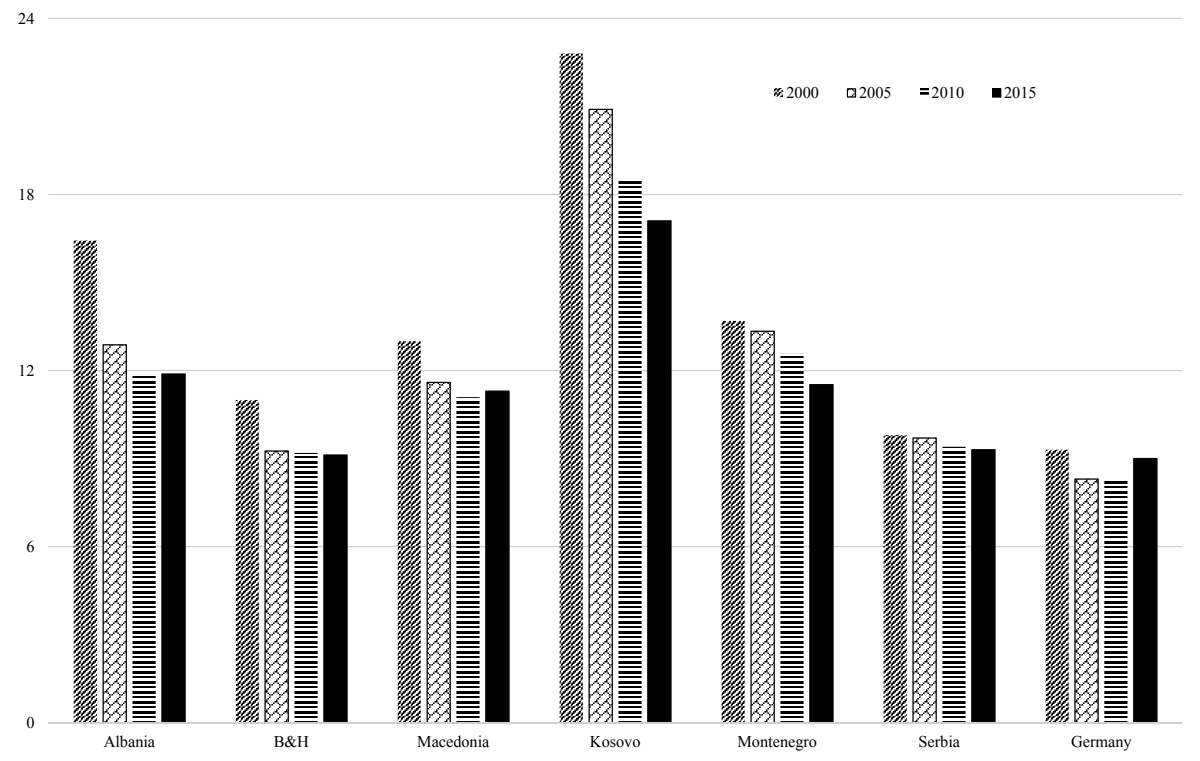

Figure 6. Birth rate, crude (per 1,000 people), 2000-2015

Source: World Bank World Development Indicators.

Note: Crude birth rate indicates the number of live births during the year, per 1,000 people, estimated at mid-year. 
However, Kosovo and Albania continue to have the highest birth rates. In the face of these unfavourable demographic trends, labour productivity would need to increase significantly to offset the future deficit in the working age population. Pension, healthcare and long-term care systems must be also adjusted to the new demographic reality.

\subsection{Monetary policy regimes and inflation}

Four Western Balkan countries do not conduct sovereign monetary policy. Kosovo and Montenegro use the euro as their currency, Bosnia and Herzegovina has a euro-denominated currency board, and Macedonia pegs to euro (in a relatively narrow horizontal band) ${ }^{11}$. The exchange rate regimes in Albania and Serbia can be characterised as managed float and both countries declare inflation targeting frameworks.

In the second half of the 1990s and the early 2000s, pegs to the German Mark and then to the euro helped Croatia, Macedonia, Bosnia and Herzegovina, Montenegro and Kosovo to disinflate quickly, given their legacies of high inflation/ hyperinflation in the early $1990 \mathrm{~s}^{12}$. However, during 2003-2017 (Figure 7) the choice of monetary regime seemed to be less important from this point of view.

Despite its inflation targeting framework, Serbia was the worst performer (at least until 2013), but Albania with the same regime recorded the lowest and most stable inflation in the region. Kosovo, Montenegro and Bosnia and Herzegovina experienced significant volatility and also Macedonia to a lesser degree. This means that small open economies, which have given up their monetary sovereignty, experience more volatile inflation because of its exogenous character driven by real and financial shocks in external markets and changes in exchange rates between major currencies. However, it is fair to say that in 2014-2017, all Western Balkan countries converged to low and relatively stable inflation rates.

The choice of monetary regime did not matter for resilience to crisis-related shocks. Figure 2 shows that the growth rates of Albania (flexible exchange rate) and Kosovo (unilateral euroisation) were the least affected by the global financial crisis, while Montenegro (unilateral euroisation) and Serbia (flexible exchange rate) were the most seriously affected. That is, nominal depreciation of national

11 IMF (2016, Table 2) classifies the exchange rate regime of Macedonia as the "stabilised arrangement" anchored to the euro.

12 Serbia and Montenegro, which formed (for a certain time) a new Yugoslav federation in 1992, suffered from the second fastest hyperinflation in world history. Over 25 months between January 1992 and February 1994, its consumer price index increased by a factor of 78,000,000,000,000,000,000,000! (Koen - De Masi 1997). 


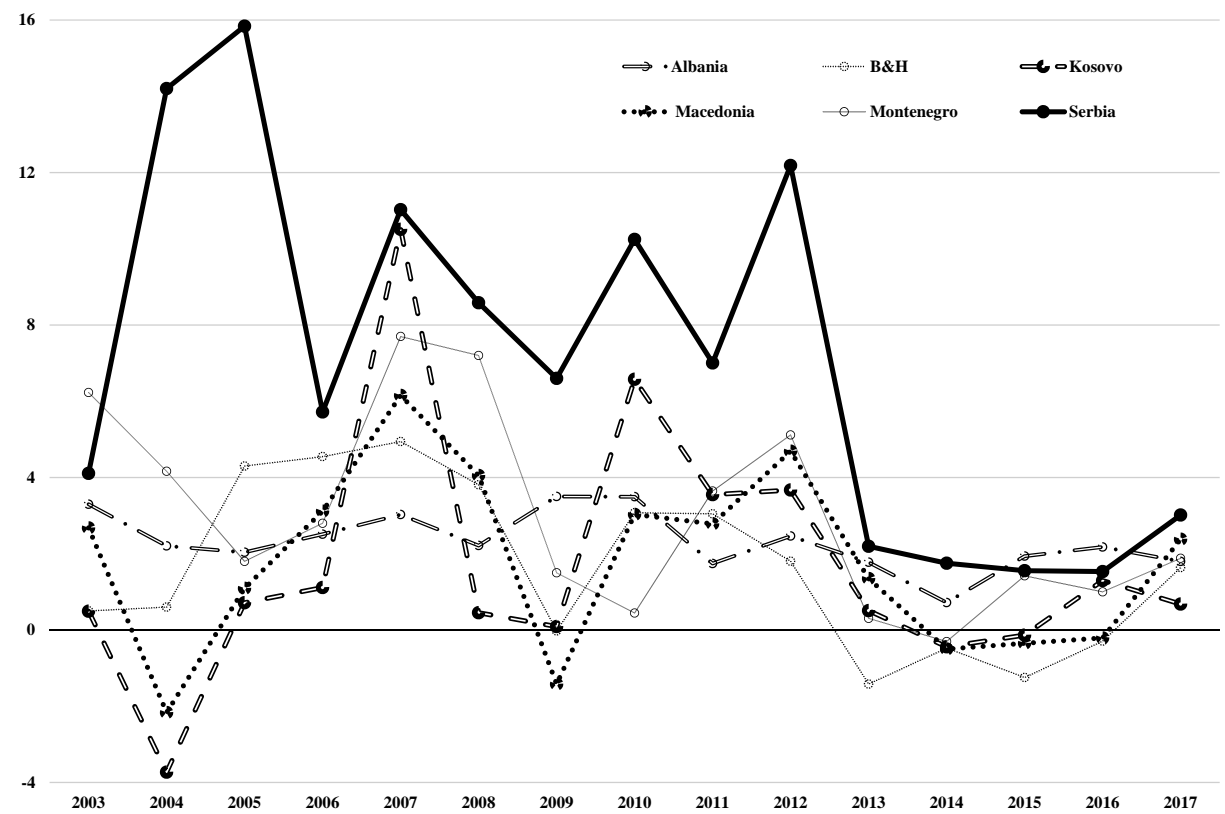

Figure 7. Inflation, end-of-period consumer prices, 2003-2017, \%

Source: IMF World Economic Outlook database, April 2018.

currency was not necessarily a better adjustment tool in comparison with the socalled internal devaluation (decreasing nominal wages and prices) that countries using euro, having currency board or stable peg had to rely on.

Monetary regimes can really matter for financial stability. All Western Balkan countries, regardless their declared and actual monetary regimes, are heavily euroized (Table 3; note this data does not include Euro or Dollar cash holdings). This is not a problem in Kosovo and Montenegro, where the euro has been adopted as the official national currency, but it is a serious vulnerability in other countries.

Furthermore, despite successful disinflation and repeated recommendations from the IMF (see, for example, IMF 2017a, b, c) there has been no visible progress in reducing euroization (Table 3 ) in favour of assets and liabilities in national currencies. From that perspective a hard peg (unilateral euroization or a credible currency board) can be seen as the factor that increases financial stability (thanks to the elimination of currency depreciation risk) and recognises high exposure of the region to euro-denominated transactions in trade, tourist services and remittance flows, among others. 
Table 3. Share of foreign-exchange denominated liabilities and loans in total liabilities in loans, 2006-2016, \%

\begin{tabular}{l|c|c|c|c|c|c|c|c}
\hline \multirow{2}{*}{ Country } & \multicolumn{4}{|c|}{$\begin{array}{c}\text { Foreign-exchange denominated } \\
\text { liabilities }\end{array}$} & \multicolumn{4}{c}{$\begin{array}{c}\text { Foreign-exchange denominated } \\
\text { loans }\end{array}$} \\
\cline { 2 - 10 } & 2006 & 2010 & 2013 & 2016 & 2006 & 2010 & 2013 & 2016 \\
\hline Albania & n.a. & 50.5 & 50.0 & 52.1 & n.a. & 68.6 & 61.9 & 57.8 \\
\hline $\begin{array}{l}\text { Bosnia and } \\
\text { Herzegovina }\end{array}$ & 62.8 & 67.0 & 63.8 & 57.4 & 71.0 & 70.0 & 68.8 & 62.6 \\
\hline Kosovo & n.a. & 4.6 & 4.6 & n.a. & n.a. & 0.2 & 0.1 & \\
\hline Macedonia & 56.9 & 57.6 & 50.2 & 46.3 & 52.7 & 58.8 & 52.7 & 44.9 \\
\hline Serbia & n.a. & n.a. & 76.7 & 71.1 & n.a. & n.a. & 71.6 & 69.4 \\
\hline
\end{tabular}

Source: IMF Financial Soundness Indicators for Albania, Bosnia and Herzegovina, Kosovo and Macedonia, IMF (2017c, Table 8) for Serbia.

Note: Data for Montenegro is not available.

\subsection{Fiscal accounts}

Most Western Balkan countries reported fiscal surpluses or positions close to fiscal balance during the pre-crisis period of the early and mid-2000s, with the exception of Albania, which ran continuous high general government deficits until 2015 (Table 4).

Table 4. General government net lending/borrowing, 2003-2017, \% of GDP

\begin{tabular}{l|r|r|r|r|r|r|r|r|r|r|r|r|r|r|c}
\hline Country & 2003 & 2004 & 2005 & 2006 & 2007 & 2008 & 2009 & 2010 & 2011 & 2012 & 2013 & 2014 & 2015 & 2016 & 2017 \\
\hline Albania & -5.0 & -5.2 & -3.5 & -3.3 & -3.2 & -4.9 & -6.6 & -3.5 & -3.5 & -3.4 & -5.2 & -5.5 & -4.1 & -1.8 & $-1.4^{\mathrm{a}}$ \\
\hline $\begin{array}{l}\text { Bosnia and } \\
\text { Herzegovina }\end{array}$ & -0.4 & -0.2 & 0.8 & 2.1 & 0.2 & -3.9 & -5.3 & -4.1 & -2.7 & -2.7 & -1.8 & -2.9 & -0.2 & 0.3 & $1.9^{\mathrm{a}}$ \\
\hline Kosovo & 1.6 & -4.6 & -3.1 & 2.7 & 7.0 & -0.2 & -0.6 & -2.2 & -1.8 & -2.6 & -3.1 & -2.4 & -1.8 & -1.2 & $-1.2^{\mathrm{a}}$ \\
\hline Macedonia & -0.1 & 0.4 & 0.2 & -0.5 & 0.6 & -0.9 & -2.6 & -2.4 & -2.5 & -3.8 & -3.8 & -4.2 & -3.5 & -2.7 & -2.7 \\
\hline Montenegro & -4.1 & -2.5 & -1.4 & 4.3 & 8.4 & -2.3 & -6.7 & -4.9 & -6.7 & -5.8 & -4.5 & -0.7 & -6.2 & -6.2 & $-7.1^{\mathrm{a}}$ \\
\hline Serbia & -2.7 & 0.1 & 1.1 & -1.0 & -0.9 & -1.9 & -3.6 & -3.7 & -4.1 & -6.8 & -5.3 & -6.2 & -3.6 & -1.2 & $1.2^{\mathrm{a}}$ \\
\hline
\end{tabular}

Source: IMF World Economic Outlook database, April 2018.

Note: ${ }^{\mathrm{a}}$ IMF staff estimates.

However, since 2008, the situation has deteriorated everywhere, though Bosnia and Herzegovina has suffered less than others. There was some improvement in Albania, Bosnia and Herzegovina and Serbia in 2016-2017.

The changes in fiscal balances have had an impact on the level of general government gross debt to GDP (Figure 8). In particular, the global financial crisis of 2008-09 reversed the previous trend of decreasing debt-to-GDP ratios. As a result, in 2017, general government gross debt exceeded 70\% of GDP in Albania and was close to that level in Montenegro, posing a serious risk to their fiscal sustainability. In Serbia, it still exceeded the level of $60 \%$ of GDP despite its decline 


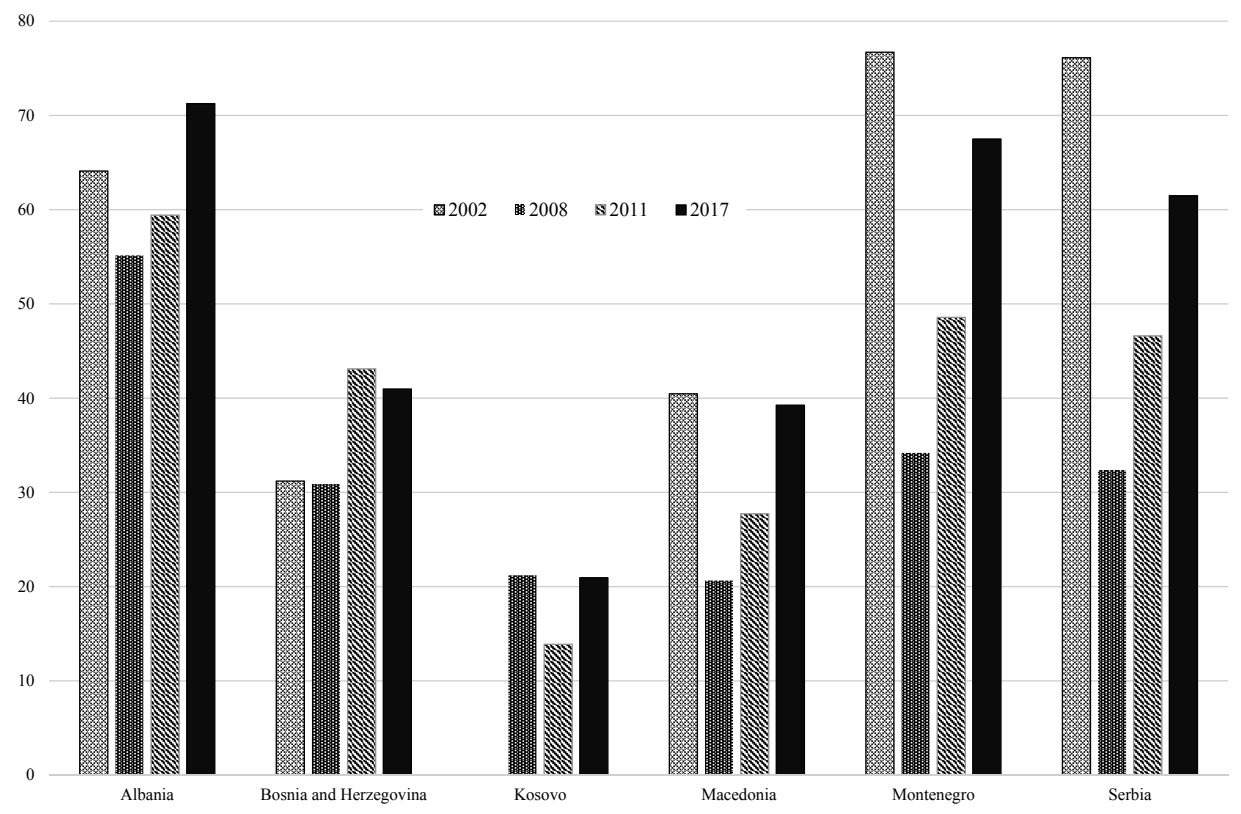

Figure 8. General government gross debt, \% of GDP, 2000-2017

Source: IMF World Economic Outlook database, April 2018.

in 2016-2017 by more than 14 percentage points of GDP. This country recorded a very high level of public debt in the early 2000 s (225\% of GDP in 2000) - a legacy of the 1990s with its economic and political turmoil, UN sanctions and engagement in violent regional conflicts. It managed to bring it down to the modest $32.4 \%$ of GDP in 2008 but allowed its increase again due to the 2008-2009 financial crisis.

\section{EXTERNAL ECONOMIC RELATIONS AND THE ROLE OF THE EU}

In this section, we analyse trade flows of the Western Balkan countries, outward migration and labour remittances, incoming FDI and official development assistance (ODA) to the region.

\subsection{Trade}

Trade and economic integration with the EU have been major growth factors in transition economies since the beginning of the 1990s (Roaf et al. 2014). This was also the case for the Western Balkan region after the end of the 1990s politi- 
cal and economic turmoil. At first glance, the Western Balkan countries' imports and exports seem to represent high shares of GDP (Figures 9 and 10). However, such an observation might not tell us the entire story.

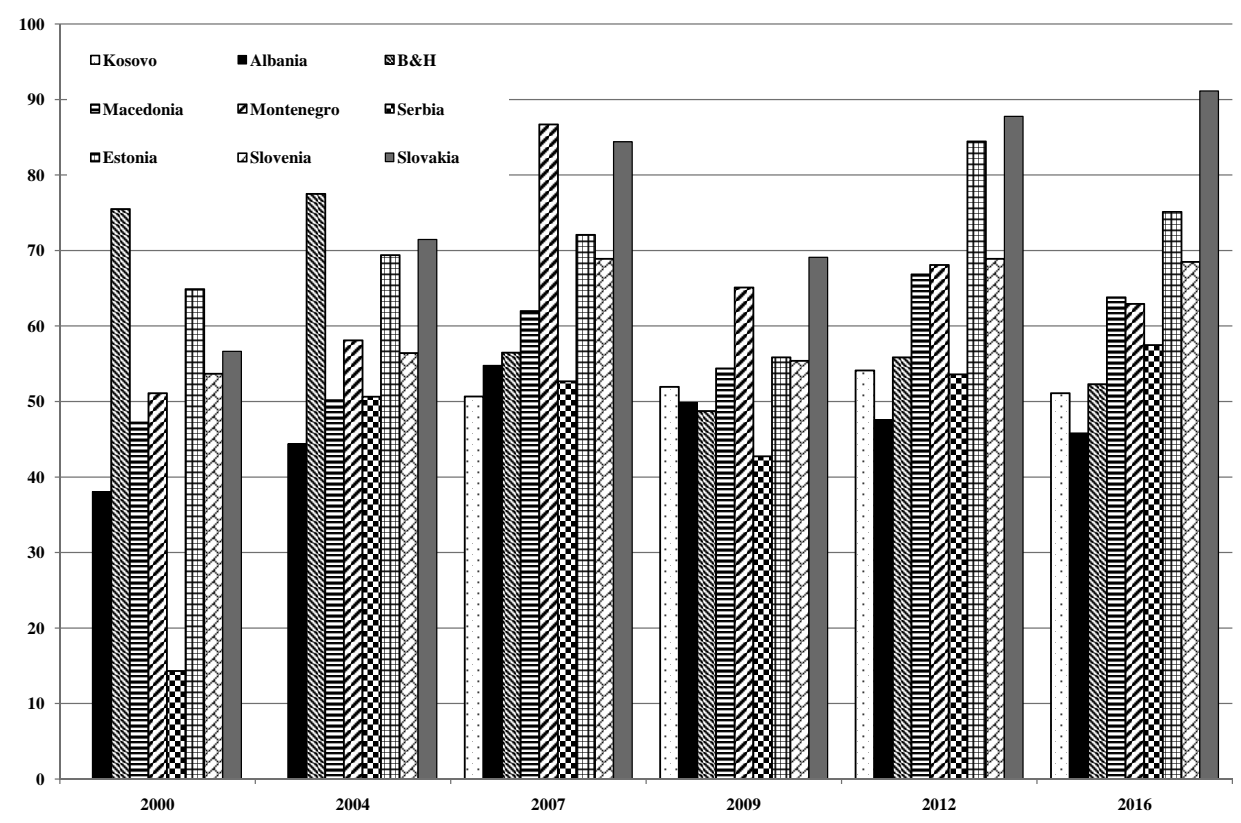

Figure 9. Imports of goods and services, \% of GDP, 2000-2016

Source: World Bank World Development Indicators.

(i) High shares of exports and imports relative to GDP are a natural phenomenon in small economies. When compared to three small economies that joined the EU in 2004 and have since introduced the euro (Slovenia, Slovakia and Estonia), the differences, especially on the export side, are visible. Even if the gap has been reduced since 2000 (Figures 9 and 10), there is still a long way to go to catch up with the benchmark countries, especially for Kosovo, Albania and Bosnia and Herzegovina.

(ii) In some cases (Montenegro, Macedonia, Albania) imports and exports relative to GDP have been volatile, not only during the global financial crisis (2008-2009), which affected negatively almost all the analysed countries.

(iii) The comparison of import and export shares relative to GDP (Figures 9 and 10) makes it clear that all countries have large trade deficits, which are partly compensated by the positive factor income balances, mainly flows of labour remittances (Section 4.2 and Table 6). The large current account imbalances 


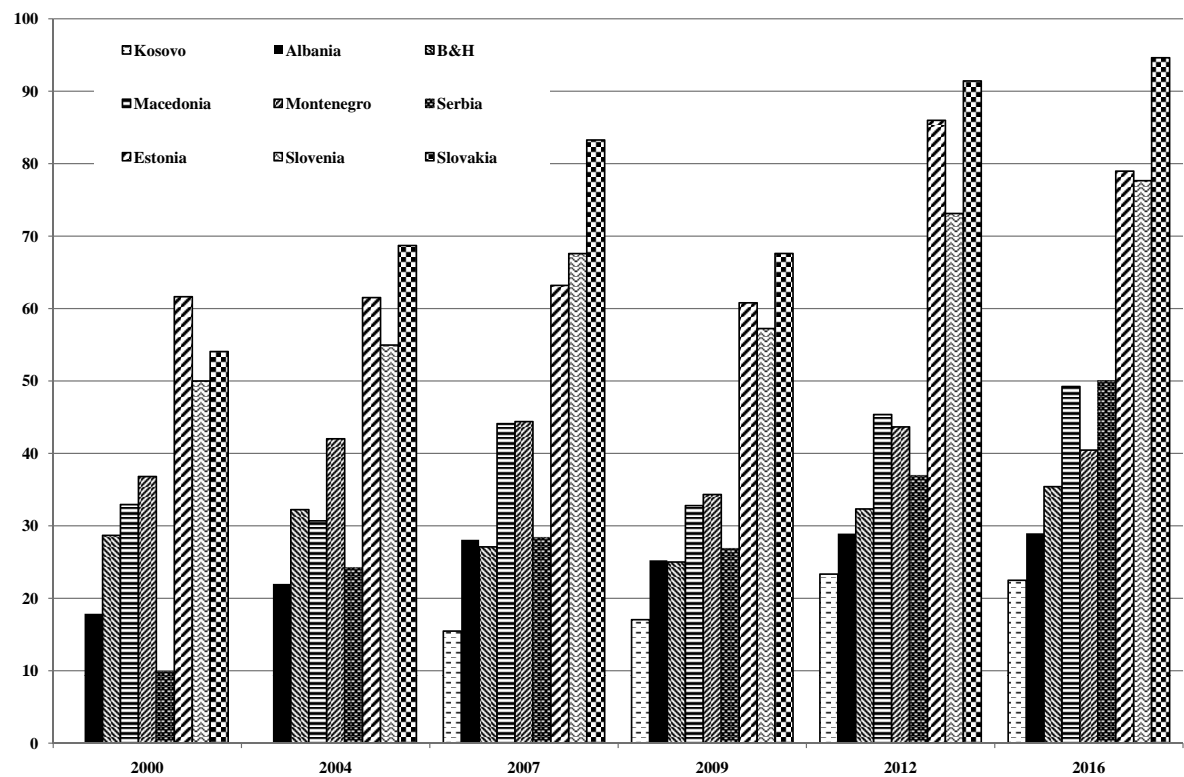

Figure 10. Exports of goods and services, \% of GDP, 2000-2016

Source: World Bank World Development Indicators.

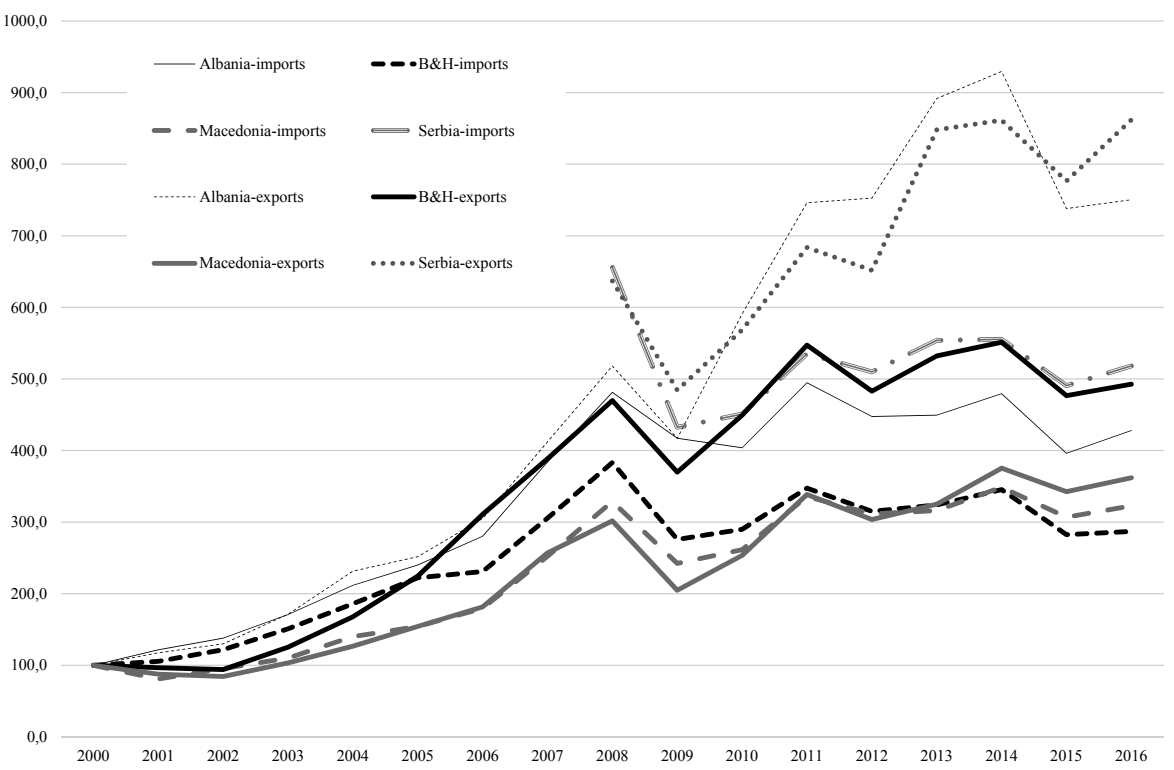

Figure 11. Value of imports and exports, 2000-2016, 2000=100

Source: World Bank World Development Indicators. 
(Figure 12), especially in Montenegro, have been historically financed by inflows of FDI (section 4.3 and Table 7) and ODA (Section 4.4 and Figure 16). However, the volume of ODA has been diminishing over time and the net private capital inflows also went down after the global financial crisis of 2008-2009. Therefore, the current account and trade balances have had to adjust and this has been achieved by faster growth of exports than of imports (Figure 11). Nevertheless, Montenegro's current account deficits continued to be very high by international comparison, even after the 2008-2009 crisis. They increased again in 2015-2017 once the economic recovery had been started.

According to the World Bank (2017), services account for more than two thirds of the total exports of goods and services, with an overall low export sophistication. In 2013, according to the UNCTAD trade database, travel and tourism played a major role in service exports from Albania, Bosnia and Herzegovina and Montenegro, while other services dominated exports from Macedonia and Serbia (data for Kosovo was missing). Other services were also the largest item in the structure of service imports in all countries except Albania, where travel and tourism services dominated the import side. In most cases, exports of goods

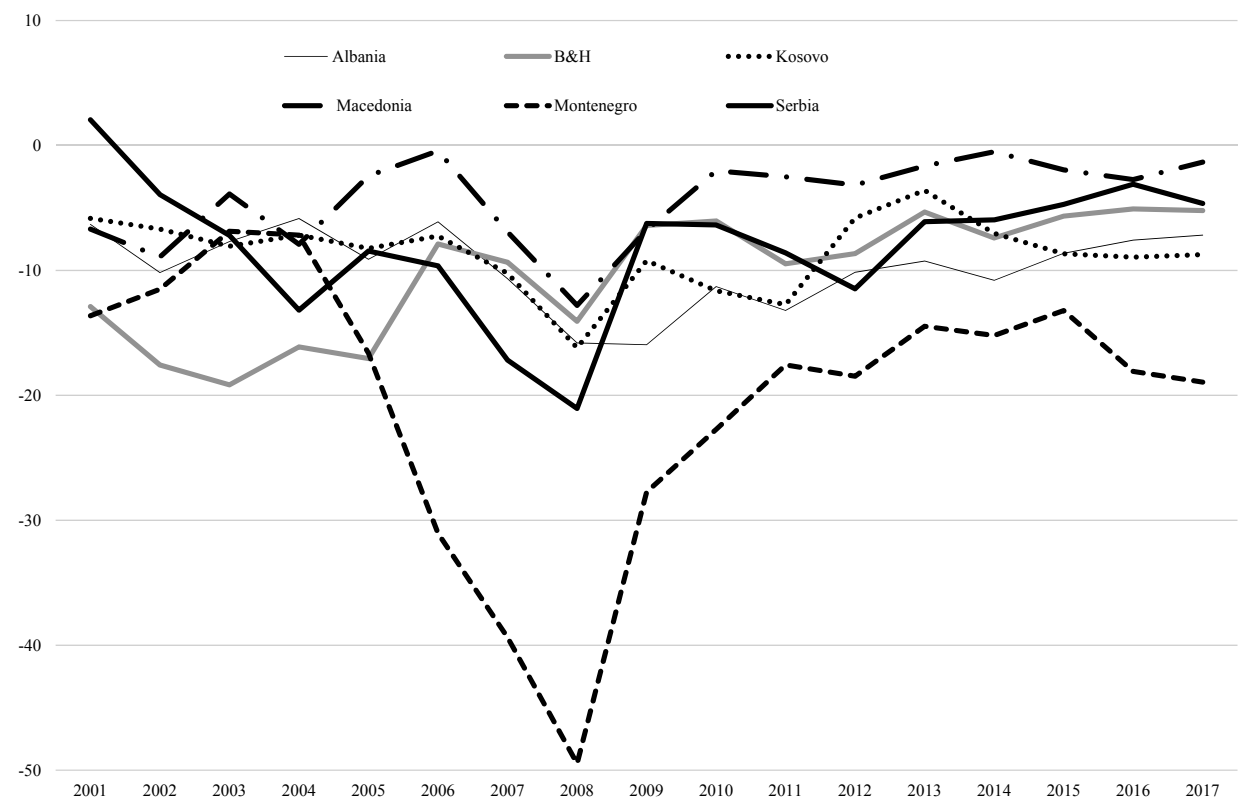

Figure 12. Current account balances, \% of GDP, 2001-2017 
were dominated by metals, minerals, agriculture and food products, textiles and footwear and chemical products. Only Serbia and Macedonia represented a more diversified export structure (Koloyanchev et al. 2018).

Figures 13 and 14 show that the EU and Western Balkan neighbours are the dominant trade partners of each Western Balkan country, accounting to at least $70 \%$ of their total trade together. For Western Balkan countries' exports, this dominance is even stronger. That is, the region is already closely integrated with the EU in terms of trade links, even if the EU's share has declined slightly compared to 2006. Nevertheless, the potential of intra-regional trade remains untapped due to continuous non-tariff barriers and poor transportation infrastructure (Koloyanchev et al. 2018).

Among other partners, Russia has played some role in supplying the region, especially Serbia, Macedonia and Bosnia and Herzegovina with energy resources (oil and gas) but Russia's role has gradually diminished over time (despite Russia's interest in the Western Balkans energy sector and the Druzhba and Adrian pipelines). Russia is also one of the destinations for Serbian exports, but not ex-

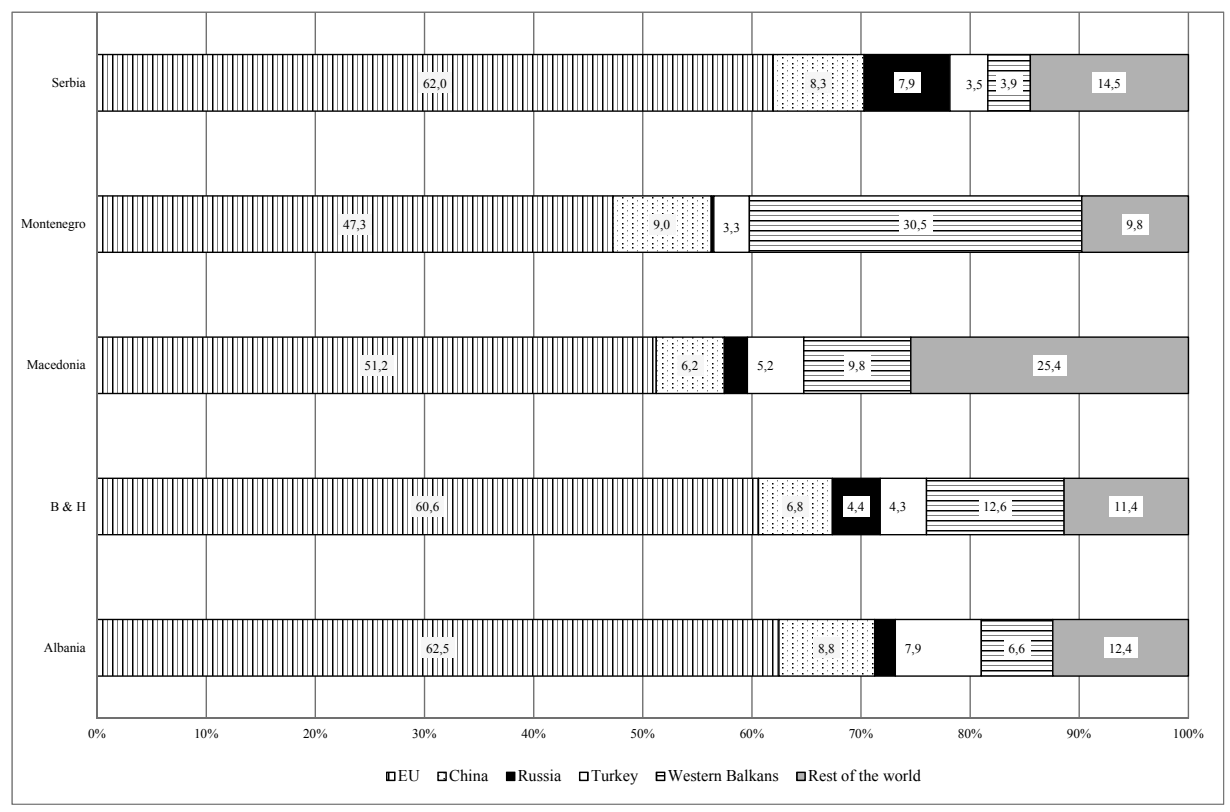

Figure 13. Geographical structure of imports, \% of total, 2016

Source: International Trade Center (Trade Map).

Note: Kosovo is omitted because of missing data. 


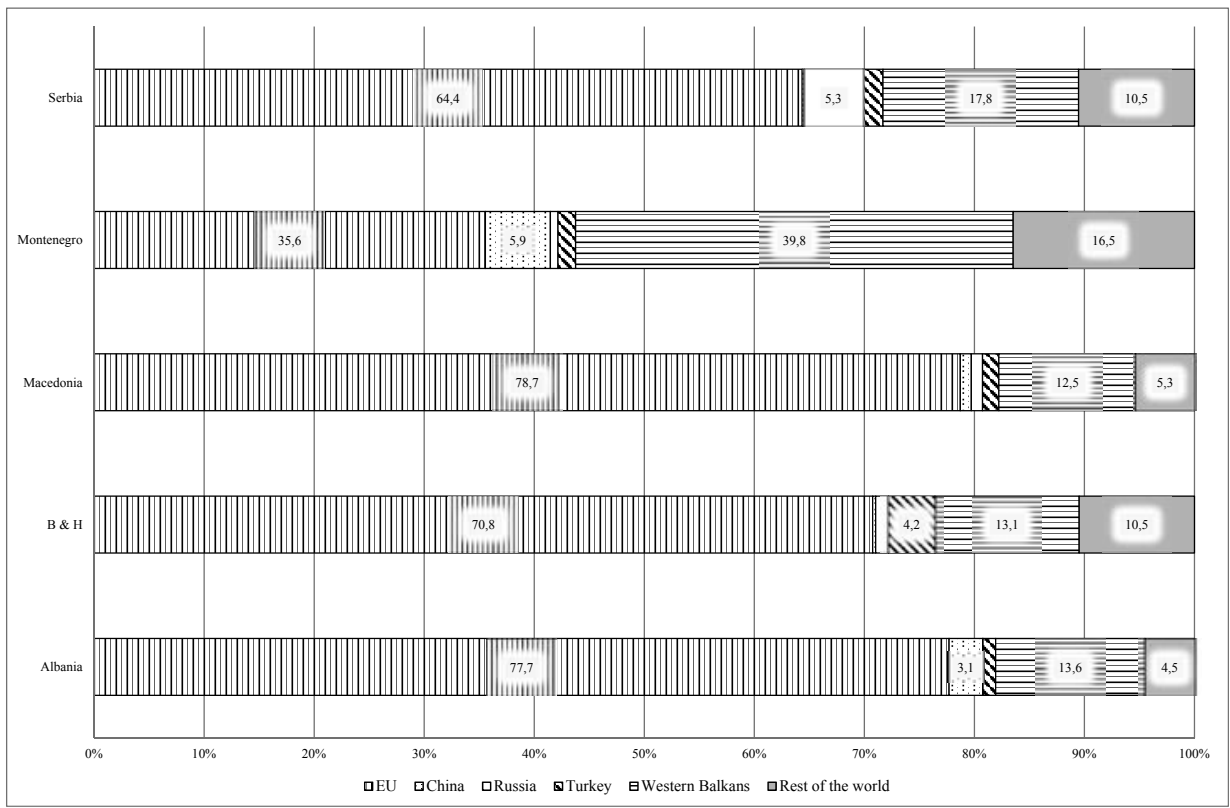

Figure 14. Geographical structure of exports, \% of total, 2016

Source: International Trade Center (Trade Map).

Note: Kosovo is omitted because of missing data.

ceeding a few per cent of the total. The shares of China and Turkey are also limited and concentrated on the import side. However, the growth in imports from both countries is very high, so their shares might increase in future.

\subsection{Outward migration and remittances}

Not surprisingly, a large proportion of the Western Balkan population has emigrated to more developed countries (in particular to Western and Northern Europe), as a result of the violent conflicts of the 1990s, lower income per capita and chronic high unemployment, especially among young people (see Section 3). Mass emigration started in 1960s from the former Yugoslavia and in the early 1990s from Albania. Albania and Bosnia and Herzegovina had the largest number and shares of their nationals living abroad in $2015^{13}$ (Table 5).

13 The numbers do not include short-term (seasonal) labour migrants. 
Table 5. Total migrant stock, number of people and \% of population, 2015

\begin{tabular}{l|c|c|c|c|c}
\hline Country of origin & Albania & $\begin{array}{c}\text { Bosnia and } \\
\text { Herzegovina }\end{array}$ & Montenegro & Serbia & Macedonia \\
\hline $\begin{array}{l}\text { Migrants stock } \\
\text { worldwide }\end{array}$ & $1,122,910$ & $1,650,772$ & 138,356 & 964,585 & 516,024 \\
\hline$\%$ of population & 38.4 & 46.7 & 22.0 & 10.9 & 24.8 \\
\hline
\end{tabular}

Source: United Nations, Department of Economic and Social Affairs, Population Division (2015, 2017). Trends in International Migrant Stock: Migrants by Destination and Origin (United Nations database, POP/DB/MIG/ Stock/Rev.2015); World Population Prospects: The 2017 Revision, DVD Edition and authors' calculations. http://www.un.org/en/development/desa/population/migration/data/estimates2/estimates 15. shtml.

Note: Estimates refer to the total number of international migrants by country of origin and refer to 1 July of the reference year (2015). In estimating the international migrant stock, international migrants have been equated with the foreign-born population whenever this information is available.

Personal remittances play an important economic and social role in all Western Balkan countries except Macedonia (Table 6). In Kosovo and Bosnia and Herzegovina their share of GDP exceeds 10\%; in Albania, Montenegro and Serbia they amount to slightly less than $10 \%$. Since 2000 , their relative importance has gradually decreased in Bosnia and Herzegovina, Kosovo, Albania and Macedonia, while it has increased in Montenegro and remained broadly stable in Serbia.

Table 6. Personal remittances, received, \% of GDP

\begin{tabular}{l|r|r|r|r|r|r|r|r|r|r|r|r|r|r|r|r|r}
\hline Country & 2000 & 2001 & 2002 & 2003 & 2004 & 2005 & 2006 & 2007 & 2008 & 2009 & 2010 & 2011 & 2012 & 2013 & 2014 & 2015 & 2016 \\
\hline Albania & 16.4 & 17.2 & 16.5 & 15.5 & 15.9 & 15.8 & 15.1 & 13.7 & 14.5 & 14.3 & 13.4 & 12 & 11.5 & 8.6 & 8.6 & 9.2 & 8.9 \\
\hline $\begin{array}{l}\text { Bosnia and } \\
\text { Herzegovina }\end{array}$ & 28.7 & 26.1 & 22.5 & 20.8 & 20.5 & 18.2 & 16.7 & 17 & 14.2 & 12.1 & 10.6 & 10.5 & 10.7 & 10.7 & 11.4 & 11.1 & 10.9 \\
\hline Kosovo & & & & & 17.1 & 18.8 & 18.9 & 19 & 18.3 & 18.7 & 17.3 & 14.9 & 14.6 & 14 & 14.9 & 15.1 & 14.8 \\
\hline Montenegro & & & & & & & & 5.4 & 6.6 & 7.3 & 8.1 & 8.8 & 9.7 & 9.5 & 9.4 & 9.4 & 9.1 \\
\hline Macedonia & 2.1 & 2 & 2.6 & 3.5 & 3.7 & 3.6 & 3.9 & 4.1 & 4.1 & 4.1 & 4.1 & 4.1 & 4 & 3.5 & 3.2 & 3.1 & 2.7 \\
\hline Serbia & & & & & & & & 9.3 & 7.2 & 10.9 & 10.4 & 8.5 & 8.7 & 8.8 & 8.4 & 9.1 & 8.4 \\
\hline
\end{tabular}

Source: World Bank's World Development Indicators.

Note: Personal remittances comprise personal transfers and compensation of employees.

\subsection{Foreign direct investment (FDI)}

The Western Balkans' deep economic integration with the EU is seen not only in terms of trade and migration (sections 4.2-4.3), but also in investment. Most FDI in the Western Balkan countries, except Kosovo, originates from the EU (Figure 15). Progress in EU accession might bring even more European FDI (Stehrer - Holzner 2018). Other major sources of FDI in the Western Balkans include Switzerland (entire region), Canada (Albania), Serbia (Bosnia and Herzegovina, Montenegro), Russia (Montenegro, Bosnia and Herzegovina, Serbia), Turkey (Albania, Kosovo, Macedonia) and Norway (Serbia) (Hunya - Schwarzhappel 2016). 


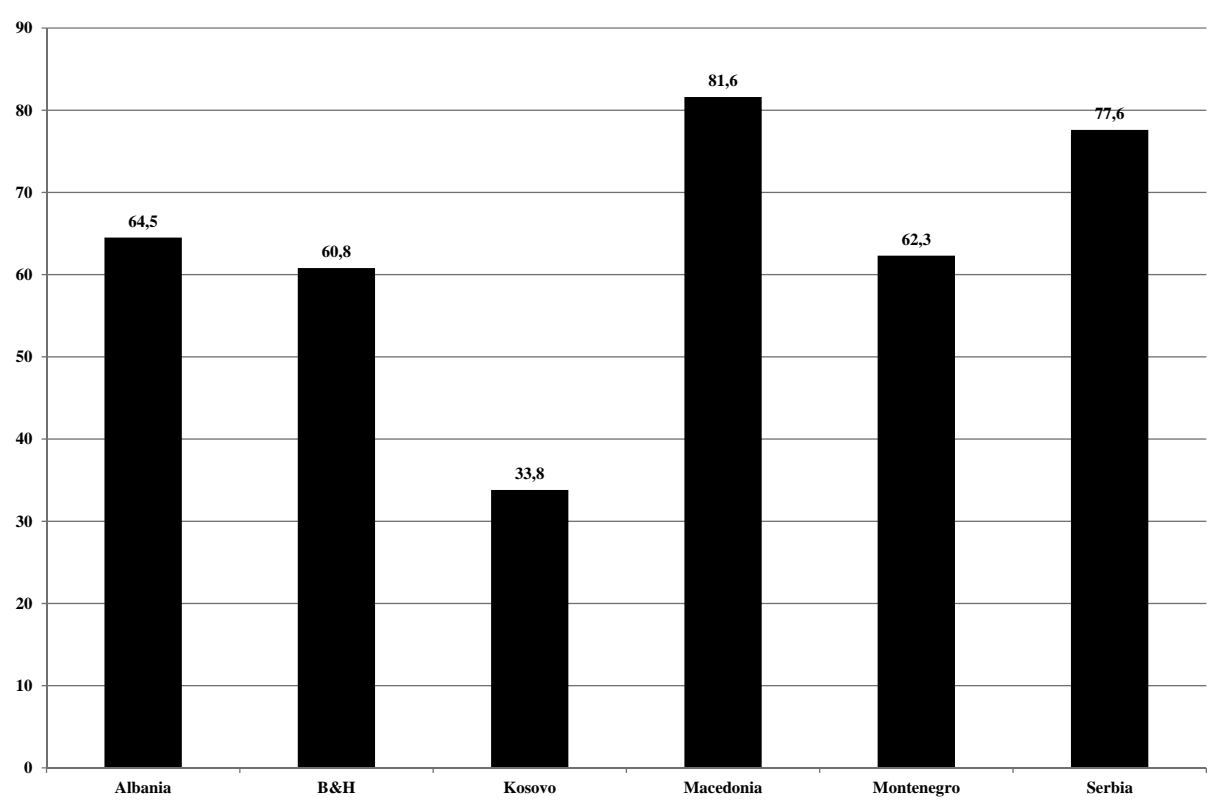

Figure 15. Share of the EU28 in the total stock of FDI in Western Balkan countries, \%, 2014 Source: Hunya - Schwarzhappel (2016).

Despite the lost decade of the 1990s, FDI inflows into the Western Balkan countries accelerated in the 2000s and 2010s, including the period following the 2008-2009 global financial crisis (Table 7) ${ }^{14}$. As a result, the cumulative stock of inward FDI relative to GDP exceeds the average in transition economies (Figure 16). Montenegro is the absolute leader with the stock of FDI in 2016 equal to $113.0 \%$ of GDP.

FDI has mainly been directed to the financial sector, telecommunications, the energy sector, wholesale and retail, construction, real estate and manufacturing (Estrin - Uvalic 2016; Hunya - Schwarzhappel 2016). For example, the region's banking sector is owned largely by foreign investors, predominantly from the EU. Many banks in the Western Balkan countries are part of the pan-European banking groups.

This concerns, for example, Raiffeisen Bank (Austria), which has its daughter banks in Albania, Bosnia and Herzegovina, Kosovo and Serbia; Intesa Sanpaolo

14 Bosnia and Herzegovina is the exception. After the 2008-2009 crisis, lower FDI inflows to this country seem to have reflected its domestic political troubles (see Section 2) and delayed prospect of EU accession. 
Table 7. Inward FDI, annual flows, \% of GDP, 2000-2016

\begin{tabular}{l|r|r|r|r|r|r|r|r|r|r|r|r|r|r|r|r}
\hline Country & 2001 & 2002 & 2003 & 2004 & 2005 & 2006 & 2007 & 2008 & 2009 & 2010 & 2011 & 2012 & 2013 & 2014 & 2015 & 2016 \\
\hline Albania & 5.3 & 3.1 & 3.2 & 4.8 & 3.3 & 3.6 & 6.2 & 7.6 & 8.3 & 8.8 & 6.8 & 6.9 & 9.9 & 8.4 & 8.2 & 9.2 \\
\hline $\begin{array}{l}\text { Bosnia and } \\
\text { Herzegovina }\end{array}$ & 2.0 & 3.8 & 4.4 & 4.9 & 5.5 & 6.0 & 11.5 & 5.2 & 1.4 & 2.4 & 2.7 & 2.3 & 1.5 & 2.9 & 1.7 & 1.7 \\
\hline Montenegro & & & & & & & & 21.1 & 36.6 & 18.4 & 12.3 & 15.2 & 10.0 & 10.8 & 17.4 & 5.5 \\
\hline Serbia & & & & & & & & 7.2 & 6.0 & 3.7 & 9.3 & 2.7 & 3.9 & 3.9 & 5.4 & 5.2 \\
\hline $\begin{array}{l}\text { Serbia and } \\
\text { Montenegro }\end{array}$ & 1.1 & 2.8 & 5.8 & 3.4 & 6.5 & 13.1 & 11.0 & & & & & & & & & \\
\hline Macedonia & 12.1 & & 2.3 & 5.7 & 1.5 & 6.3 & 8.3 & 5.9 & 2.1 & 2.3 & 4.6 & 1.5 & 3.1 & 2.4 & 2.4 & 3.9 \\
\hline $\begin{array}{l}\text { Transition } \\
\text { economies }\end{array}$ & 1.9 & 2.0 & 2.9 & 3.5 & 2.9 & 4.3 & 4.9 & 5.1 & 3.5 & 3.0 & 2.9 & 2.2 & 2.8 & 2.0 & 1.9 & 3.6 \\
\hline
\end{tabular}

Source: UNCTAD, http://unctadstat.unctad.org/wds/TableViewer/tableView.aspx.

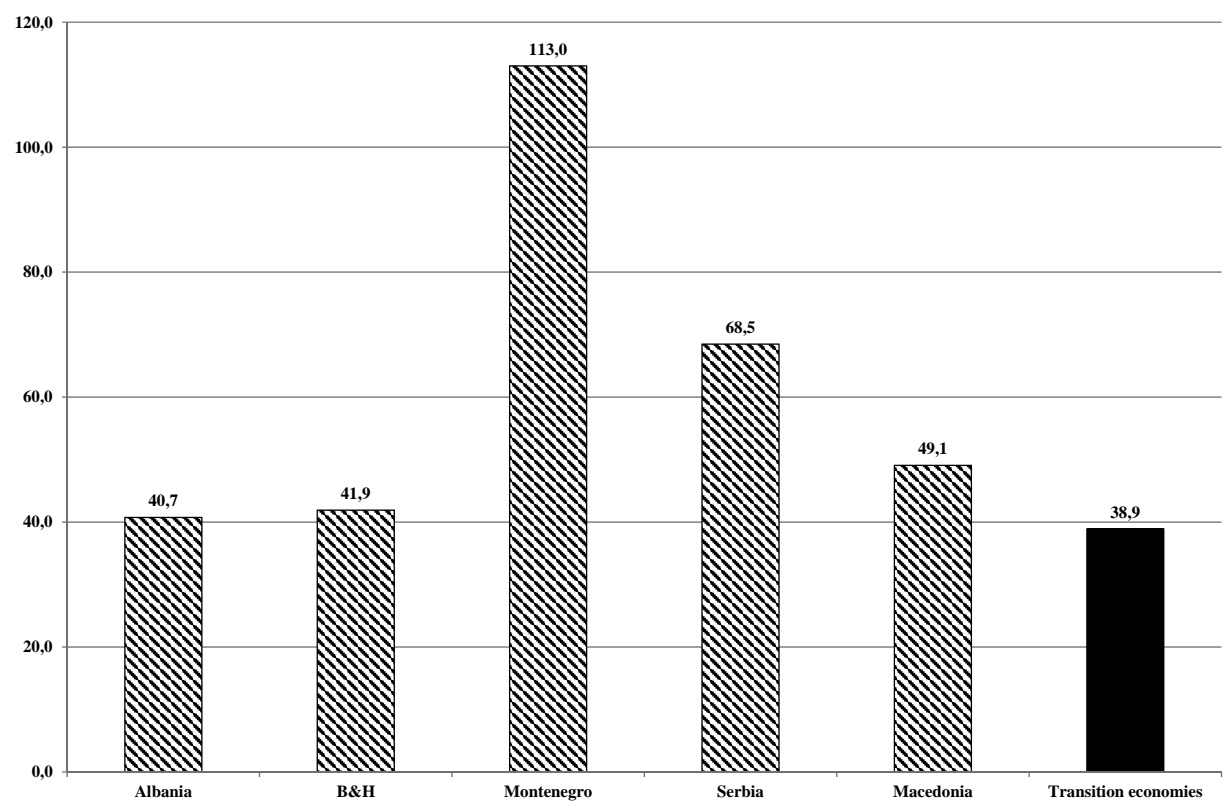

Figure 16. Stock of inward FDI, \% of GDP, 2016

Source: UNCTAD, http://unctadstat.unctad.org/wds/TableViewer/tableView.aspx.

(Italy) with subsidiaries in Albania, Bosnia and Herzegovina and Serbia; National Bank of Greece owning subsidiaries in Albania and Macedonia; UniCredit (Italy) in Bosnia and Herzegovina and Serbia; Societe Generale (France) in Albania, Macedonia and Serbia; Nova Ljubljanska Banka (Slovenia) in all Western Balkan countries except for Albania; and Pireaus Bank (Greece) in Albania and Serbia. In 2016, the share of banks with foreign ownership in total assets of banking sector varied between $73.0 \%$ in Montenegro and $85.5 \%$ in Bosnia and Herzegovina (Kozaric - Begovic 2018). 


\subsection{Official development assistance (ODA)}

In the early 2000s, the Western Balkan countries received large amounts of ODA (Figure 17), reflecting the desire of the international community to support their post-conflict recovery and reconstruction, the transition to democracy and market economy, and their integration with the EU (Sections 2 and 6). However, with their progress in economic convergence (Section 3.1), the size of ODA flows gradually diminished to between $0.9-3.0 \%$ of GNI in 2016, except for Kosovo, where they still amounted to $6.7 \%$ of GNI (having declined from $13.9 \%$ of GNI in 2009).

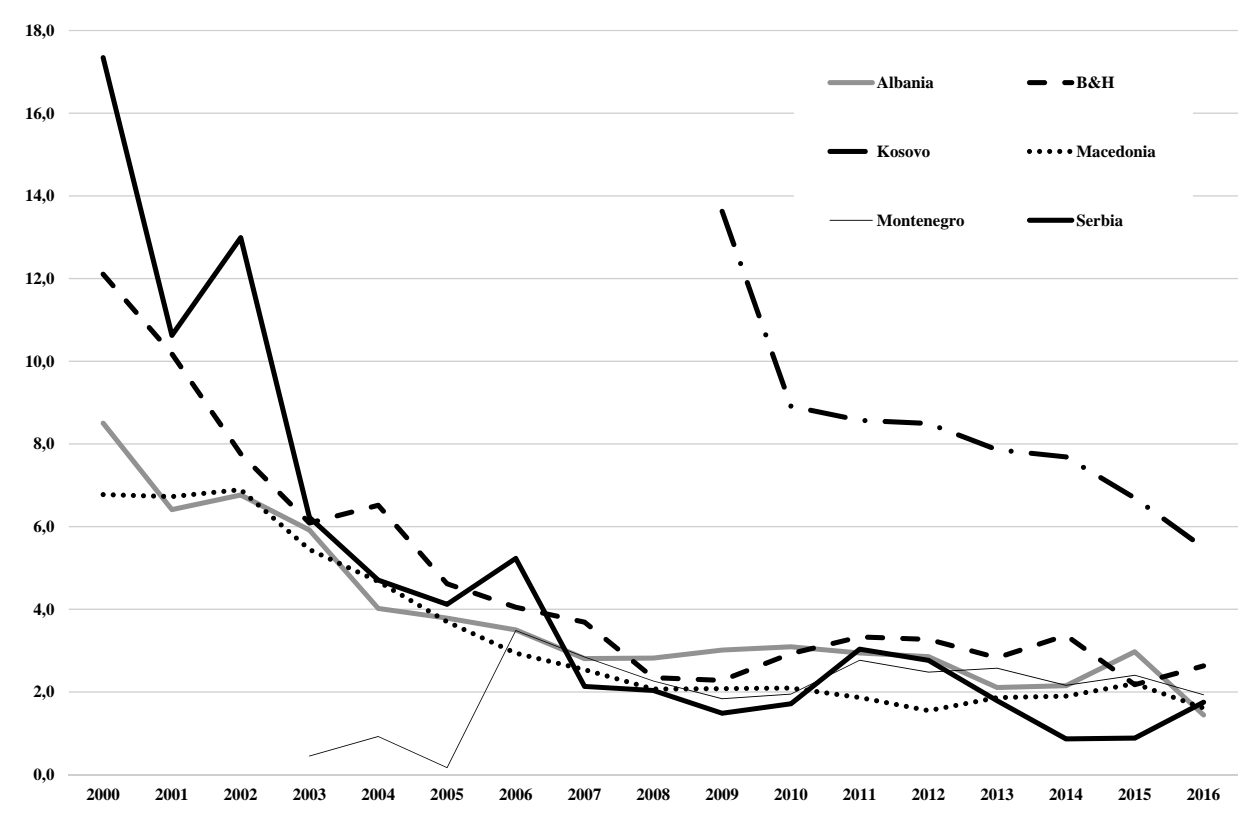

Figure 17. Net inflows of ODA, \% of GNI

Source: World Bank World Development Indicators.

\section{INSTITUTIONAL CHALLENGES}

The Western Balkan region lags behind other Central and Eastern European (CEE) countries (those that already joined the EU) in terms of institutional reforms. As noted by the World Bank (2017: 19-20), by 2013, the Western Balkan countries had made the same progress in reforms, measured by the EBRD transition scores, as the group of smaller transition European economies (STEEs) had by 1996 (Figure 18). 


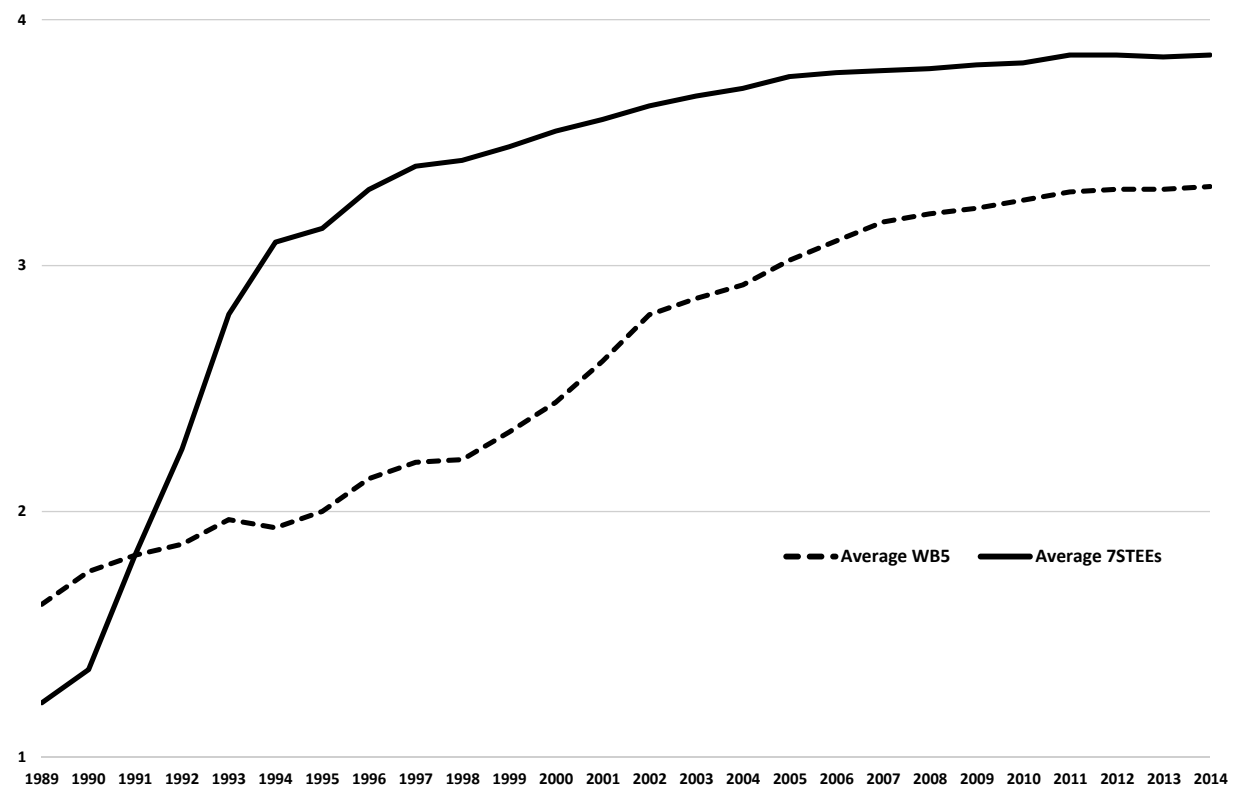

Figure 18. Average EBRD transition scores: Western Balkans and STEE countries*

Source: Bruegel based on EBRD.

Notes: EBRD transition score is calculated as the simple average of six EBRD indicators: price liberalisation, trade and foreign exchange system, small-scale privatisation, large scale privatisation, governance and enterprise restructuring, and competition policy, each rated on a scale from 1 (no reform) to 4.33 (maximum reform). Data for Kosovo is missing.

* STEEs = Bulgaria, Croatia, Estonia, Latvia, Lithuania, Slovakia and Slovenia.

Before 1991, the Western Balkan countries were moving faster on reforms than STEEs (Figure 18) thanks to the legacy of the Yugoslav 'market socialism' system. However, the political and economic turmoil of 1990s changed the situation and since then the Western Balkan countries have lagged behind. Sanfey et al. (2016) offer an optimistic prediction, arguing that the Western Balkans can narrow the gap in the coming years under the right circumstances.

The delayed reforms have a negative impact on the business climate and the entire institutional environment, slowing down economic convergence with the $\mathrm{EU}$ and the EU accession process. However, not all the global surveys rate the Western Balkan economies unfavourably. For example, the annual World Bank Doing Business 2018 Survey ranks Macedonia eleventh globally and second in the Europe and Central Asia region (that is, among all transition economies). Kosovo, Montenegro and Serbia, respectively, occupy the $40^{\text {th }}, 42^{\text {nd }}$ and $43^{\text {rd }}$ positions in this ranking. Bosnia and Herzegovina is the worst regional performer $\left(86^{\text {th }}\right.$ place $)$ but is still better than many economies of the former Soviet Union (Table 8). 
Table 8. Ease of doing business, rankings out of 190, 2018

\begin{tabular}{|c|c|c|c|c|c|c|c|c|c|c|c|}
\hline $\begin{array}{l}\text { 音 } \\
\text { 言 }\end{array}$ & 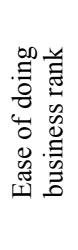 & 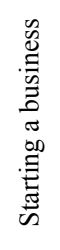 & 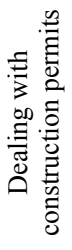 & 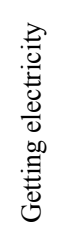 & 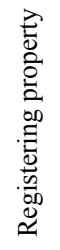 & 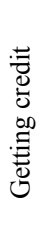 & 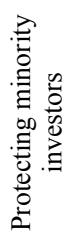 & 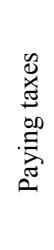 & 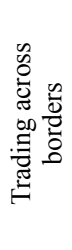 & 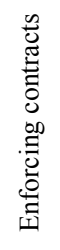 & 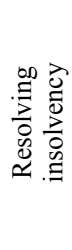 \\
\hline Albania & 65 & 45 & 106 & 157 & 103 & 42 & 20 & 125 & 24 & 120 & 41 \\
\hline $\mathrm{B} \& \mathrm{H}$ & 86 & 175 & 166 & 122 & 97 & 55 & 62 & 137 & 37 & 71 & 40 \\
\hline Macedonia & 11 & 22 & 26 & 53 & 48 & 12 & 4 & 29 & 27 & 35 & 30 \\
\hline $\begin{array}{l}\text { Montene- } \\
\text { gro }\end{array}$ & 42 & 60 & 78 & 127 & 76 & 12 & 51 & 70 & 44 & 42 & 37 \\
\hline Serbia & 43 & 32 & 10 & 96 & 57 & 55 & 76 & 82 & 23 & 60 & 48 \\
\hline Kosovo & 40 & 10 & 122 & 106 & 34 & 12 & 89 & 45 & 48 & 49 & 49 \\
\hline
\end{tabular}

Source: World Bank Doing Business 2017 Survey, http://www.doingbusiness.org/Rankings.

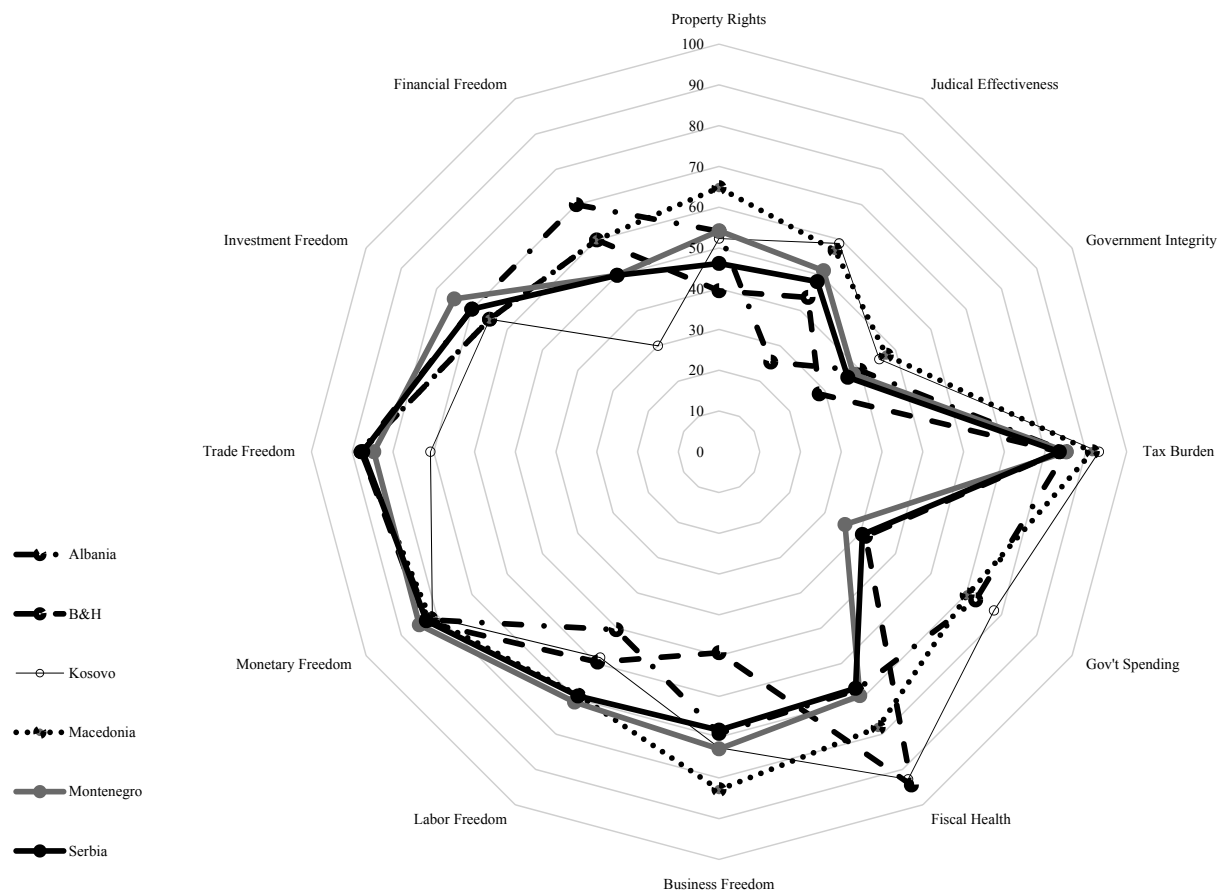

Figure 19. Heritage Foundation Index of Economic Freedom by components, 2018

Source: Heritage Foundation, https://www.heritage.org/index/explore.

Note: The score range is $1-100$. The higher the score, the better is the country performance. 
The Doing Business Survey concentrates on administrative procedures and measures ease in running company in a given regulatory environment. The indicator is based on the distance to the frontier score, which is presented by the most efficient country of the selected region in terms of the regulatory practice employed. The overall rank is based on scores granted in ten specific areas: (1) Starting a business, (2) Dealing with construction permits, (3) Getting electricity, (4) Registering property, (5) Getting credit, (6) Protecting minority investors, (7) Paying taxes, (8) Trading across borders, (9) Enforcing contracts and (10) Resolving insolvency.

Table 8 shows that Macedonia is one of the easiest economies when it comes to protecting minority investors or getting credit. Serbia proved to be the best among transition economies in dealing with construction permits, and Montenegro is also ranked high in terms of access to credit. Starting a business is relatively easy in Kosovo. However, the Western Balkan countries do not perform well in registering a property or getting electricity. On average, the region still lags behind STEEs (World Bank 2017). Unlike the World Bank Doing Business Survey, which concentrates on length, simplicity and costs of administrative procedures, the Heritage Foundation Index of Economic Freedom pays more attention to more fundamental factors, such as economic liberalisation, property rights, corruption and government integrity. Figure 19 shows that the Western Balkan countries perform especially badly in terms of government integrity, judicial effectiveness and labour freedom. All those indicators point to inefficiency in the public sector. Indicators of business freedom (except Macedonia and Albania) and property rights are also lagging.

Corruption remains a major problem in the Western Balkans, reflected in the Transparency International Corruption Perception Index (Table 9). Most countries slightly improved their ranking in 2016 compared to 2015: they were ranked

Table 9. Corruption Perception Index (CPI), 2015-2016

\begin{tabular}{l|c|c|c|c|c|c}
\hline Country & $\begin{array}{c}\text { CPI } \\
2016\end{array}$ & $\begin{array}{c}\text { CPI } \\
2015\end{array}$ & $\begin{array}{c}\text { Score difference } \\
(2016-2015)\end{array}$ & $\begin{array}{c}\text { CPI 2016 } \\
\text { Rank }\end{array}$ & $\begin{array}{c}\text { CPI 2015 } \\
\text { Rank }\end{array}$ & $\begin{array}{c}\text { Rank difference } \\
(2015-2016)\end{array}$ \\
\hline Macedonia & 37 & 42 & -5 & 90 & 66 & -24 \\
\hline Montenegro & 45 & 44 & 1 & 64 & 61 & -3 \\
\hline Bosnia and Herzegovina & 39 & 38 & 1 & 83 & 76 & -7 \\
\hline Serbia & 42 & 40 & 2 & 72 & 71 & -1 \\
\hline Albania & 39 & 36 & 3 & 83 & 88 & 5 \\
\hline Kosovo & 36 & 33 & 3 & 95 & 102 & 7 \\
\hline
\end{tabular}

Source: Transparency International, https://www.transparency.org/news/feature/corruption_perceptions index_2016\#table.

Note: The index represents a scale of 1-100. Higher scores refer to lower levels of corruption. 
between 64 (Montenegro) and 95 (Kosovo) out of 176 countries. However, Macedonia dropped dramatically in the ranking, which can be seen as contradicting its favourable Doing Business rating (Table 8).

\section{PROGRESS IN EU ACCESSION}

Since the 1980s, each candidate country starts its EU accession process by signing an association agreement (AA) and a free trade agreement (FTA) with the EU. This is followed by obtaining EU candidate status and membership negotiations aimed at setting the pace and terms of adoption of the acquis communautaire, that is, the entire body of EU law by a prospective member. After completing negotiations, both the incumbent members and the applicant countries have to formally approve the terms of enlargement through the ratification of accession treaties. In most of the candidate countries, this has taken the form of a referendum. As the EU integration has progressed and covered the new policy areas, accession negotiations have become increasingly complex and take more and more time. The same concerns the content of AAs and FTAs, which constitute the first step of the integration process.

Each step, from signing and ratifying an AA and a FTA to completing accession requires unanimous decision of all incumbent member states. The latter use this multi-step process not only to ensure that future members will be ready and able to meet all EU membership requirements (see Box 1) but also as a tool to extract bilateral concessions from candidates (the example of Greece putting pressure on Macedonia to change its official country name).

The EU candidates are subject to extensive policy conditionalities set by the incumbent EU member states and EU governing bodies, which are considered the strongest and most effective incentives for the EU applicants to conduct economic, institutional, political and social reforms (Dabrowski - Radziwill 2007). However, meeting such conditionality by the prospective candidate requires a lot of political effort and usually takes time. Furthermore, in some exceptional situations when the upfront costs are considered too high as compared to the quite distant membership perspective and the related benefits, the accession process can become stalled or derailed (the examples of Turkey and Macedonia). ${ }^{15}$

15 Article 49 of the Treaty on European Union (TEU) defines eligibility criteria to become an EU member in terms of both geography (location in Europe) and adherence to basic human rights and democratic values, with reference to Article 2 of the TEU. In turn, Article 2 of the TEU describes the values mentioned in Article 49 as '... respect for human dignity, freedom, democracy, equality, the rule of law and respect for human rights, including the rights of persons belonging to minorities.' Furthermore, they '... are common to the Member States in 
The opportunity for Euro-Atlantic integration was offered to the Western Balkan countries in 1999 in the aftermath of the Kosovo conflict. A cooperation agreement, the Stability Pact for Southern and Eastern Europe, was put in place in June 1999. This was an EU initiative, but other countries (the US, Canada, Japan, Russia, Turkey, Norway and Switzerland) and a number of international organisations were also involved. The pact had three major pillars - democracy, economy and security - and it opened the Stabilisation and Association Process (a first step towards potential EU membership) for the Western Balkan region. The Stability Pact was replaced by the Regional Cooperation Council in $2008^{16}$.

The potential eligibility of the Western Balkan countries to become EU members was confirmed by the Thessaloniki EU summit in June 2003. The European Council expressed "...its determination to fully and effectively support the European perspective of the Western Balkan countries, which will become an integral part of the EU, once they meet the established criteria" (Council of the European Union 2003: 12). Subsequently, Stabilisation and Association Agreements (SAAs), which also include provisions for a Deep and Comprehensive Free Trade Area (DCFTA $)^{17}$, were negotiated, signed and ratified by the EU and Western Balkan countries. The agreement with Macedonia entered into force in 2004, with Croatia in 2005, Albania in 2009, Montenegro in 2010, Serbia in 2013, Bosnia and Herzegovina in 2015 and Kosovo in 2016. In most cases, the trade parts of SAAs became effective earlier due to the simplified ratification procedure on the EU side (only the European Parliament).

In addition, since early 2000s the EU has promoted a network of 32 horizontal free trade agreements between countries of the region. In December 2006 in $\mathrm{Bu}-$

a society in which pluralism, non-discrimination, tolerance, justice, solidarity and equality between women and men prevail.' This means that no economic preconditions are explicitly mentioned in Articles 2 and 49.

Nevertheless the economic conditions were set by the European Council in December 1993 in Copenhagen, along with the political and institutional ones. They are called now as Copenhagen criteria and they include:

- political criteria: stability of institutions guaranteeing democracy, rule of law, human rights and respect for and protection of minorities;

- economic criteria: a functioning market economy and the capacity to cope with competition and market forces;

- administrative and institutional capacity to effectively implement the acquis and ability to take on the obligations of membership.

See http://www.rcc.int/home.

DCFTAs eliminate import tariffs and also non-tariff barriers. They liberalise trade in services and investment regimes and involve the far-reaching harmonisation of various trade and investment-related regulations and institutions, especially in the areas of competition policy, state aid and public procurement (Evans et al. 2004). 
charest, those bilateral trade agreements were consolidated under the umbrella of the Central European Free Trade Agreement (CEFTA), an integration framework created in mid-1990s by then prospective EU members from Central Europe, which joined the EU in 2004 and 2007 (Koloyanchev et al. 2018). The CEFTA currently involves all six Western Balkan countries and Moldova ${ }^{18}$. However, as mentioned in Section 4.1, CEFTA is not sufficiently ambitious in eliminating non-tariff barriers and facilitating trade in services.

Macedonia and Croatia obtained EU candidate status in 2004, Montenegro in 2010, Serbia in 2012 and Albania in 2014. Croatia started membership negotiations in 2005 and completed them in 2011, becoming the $28^{\text {th }} \mathrm{EU}$ member on 1 July 2013. Montenegro started membership negotiations in 2012 and Serbia started in January 2014. The EU candidate status of Macedonia is frozen, notwithstanding several European Commission recommendations since October 2009 to open accession negotiations (the last one was issued on 17 April 2018 (European Commission 2018b) ${ }^{19}$. The blockage has been Greece's reservations over the country's name and domestic rule of law problems (Section 2). By April 2018, Montenegro had managed to open accession negotiations on 30 out of 35 chapters of the acquis communautaire (the body of EU law). The non-started chapters are competition policy, economic and monetary policy, environment and climate change, institutions and 'other issues'. Three chapters (science and research, education and culture, and external relations) have been already provisionally closed (European Commission 2018c).

Serbia is less advanced. By April 2018, it had managed to start negotiations on only 12 chapters: public procurement, company law, intellectual property law, enterprise and industrial policy, judiciary and fundamental rights, justice, freedom and security, science and research, education and culture, customs union, external relations, financial control, and other issues. It had provisionally closed only two chapters - on science and research, and education and culture (European Commission 2018d).

\section{SUMMARY AND CONCLUSIONS}

The Western Balkan countries have been slow to reform compared to the Central European and Baltic countries as a consequence of the decade of devastating ethnic conflicts that followed the collapse of the former Yugoslavia. Since 2000, the Western Balkans have managed to move forward on the political and economic

18 See http://www.cefta.int/ for details.

19 On the same day the EC also recommended to open accession negotiations with Albania. 
reform fronts largely thanks to the prospect of EU accession that the $2003 \mathrm{EU}$ Thessaloniki summit opened up for them. They have also succeeded in partial income convergence with the EU, although there is still a long way to go. In particular, since the start of the global financial crisis in 2008, the convergence process slowed and, in most countries, even temporarily went into reverse. Economic growth has started to accelerate again only very recently, following economic recovery in the EU.

The slow pace of reform and the EU accession process might be disappointing for many and is the result of numerous unresolved legacies of the 1990s conflict era, domestic political setbacks and a decreasing appetite on the part of the incumbent EU member states for further enlargement. In this context, the recent EC initiative to reenergise the accession process and agenda, and to set an indicative deadline (2025) for admission of the two most advanced candidates - Serbia and Montenegro - must be welcomed (European Commission 2018a).

This initiative could incentivise all countries of the region, including those candidates that have not yet started membership negotiations (Macedonia and Albania) and those who wait for candidate status (Bosnia and Herzegovina and Kosovo), to remove domestic political obstacles to EU accession, solve conflicts with neighbours, speed up reforms and accelerate economic growth. The initiative could also help to avoid the worst-case scenario - the derailing of the entire reform and European integration process (as happened with Turkey) and the descent again into the ethnic conflict trap.

To give the new momentum a real chance of success, political will on the part of the EU governing bodies is not enough. Candidate and potential candidate countries must be ready to intensify their reform homework, including the most difficult issues of conflict legacies, human rights, guarantees for ethnic, religious and other minorities, respect for the rule of law, full normalisation of relations with neighbours, the fight against corruption, state capture and organised crime, and the modernisation of the public administration and judiciary. The experience of the previous EU enlargement rounds suggests that it makes sense to address up front the most difficult political, institutional and governance issues to avoid disappointment on both sides. This is what the EC (2018a) is rightly suggesting in its Western Balkans strategy. 


\section{REFERENCES}

Bechev, D. (2012): The Periphery of the Periphery: The Western Balkans and the Euro Crisis. Policy Brief, No. 60, European Council on Foreign Relations, http://www.ecfr.eu/publications/ summary/the periphery_of the periphery_the_western_balkans_and the euro_crisis

Bechev, D. (2018): Stability and Crisis in the Western Balkans. ISPI - Italian Institute for International Political Studies, Commentary, 16 May, https://www.ispionline.it/en/pubblicazione/ stability-and-crisis-western-balkans-20289

Byrne, A. - Mitchell, T. (2017): Eastern Europe Welcomes China Investment promise. Financial Times, 28 November.

Council of the European Union (2003): Thessaloniki European Council 19 and 20 June 2003: Presidency Conclusions. Document 11638/03, http://www.consilium.europa.eu/uedocs/cms_data/ docs/pressdata/en/ec/76279.pdf

Dabrowski, M. - Myachenkova, Y. (2018): The Western Balkans on the Road to the European Union. Breugel Policy Contribution, No. 04.

Dabrowski, M. - Radziwill, A. (2007): Regional vs. Global Public Goods: The Case of Post-Communist Transition. CASE Network Studies and Analyses, No. 336, http://www.case-research.eu/ sites/default/files/publications/13493806_sa336_0.pdf

EIU (2018): Western Balkans to 2025: A Brighter Future or Permanent Marginalisation? The Economist Intelligence Unit.

Estrin, S. - Uvalic, M. (2016): Foreign Direct Investment in the Western Balkans: What Role has It Played during Transition? Comparative Economic Studies, 58(3): 455-483.

European Commission (2018a): A Credible Enlargement Perspective for and Enhanced EU Engagement with the Western Balkans. Communication COM(2018) 65 final, https://ec.europa. $\mathrm{eu} / \mathrm{commission} /$ sites/beta-political/files/communication-credible-enlargement-perspectivewestern-balkans_en.pdf

European Commission (2018b): The Former Yugoslav Republic of Macedonia 2018 Report. Commission Working Staff Document, SWD (2018) 154 final, Strasbourg, 17 April, https://ec.europa. eu/neighbourhood-enlargement/sites/near/files/20180417-the-former-yugoslav-republic-ofmacedonia-report.pdf

European Commission (2018c): Montenegro 2018 Report. Commission Working Staff Document, SWD (2018) 150 final, Strasbourg, 17 April, https://ec.europa.eu/neighbourhood-enlargement/ sites/near/files/20180417-montenegro-report.pdf

European Commission (2018d): Serbia 2018 Report. Commission Working Staff Document, SWD (2018) 152 final, Strasbourg, 17 April, https://ec.europa.eu/neighbourhood-enlargement/sites/ near/files/20180417-serbia-report.pdf

European Council (2018): Sofia Declaration, 17 May 2018, EU - Western Balkans Summit, http:// www.consilium.europa.eu/media/34776/sofia-declaration en.pdf

Evans, D. - Holmes, P. - Iacovone, L. - Robinson, S. (2004): A Framework for Evaluating Regional Trade Agreements: Deep Integration and New Regionalism. University of Sussex, mimeo.

Dragutinović-Mitrović, R. - Bjelić, P. (2015): Trade Regimes and Bilateral Trade in the EU Enlargement Process: Focus on the Western Balkans. Acta Oeconomica, 65(2): 249-270.

Fouere, E. (2017): Western Balkans and the EU: Still in Stand-by. Commentary, Italian Institute for International Political Studies, 10 July, http://www.ispionline.it/en/pubblicazione/westernbalkans-and-eu-still-stand-17166

Fouere, E. (2018): Progress in Resolving the Greek-Macedonian Name Dispute - Will It Break the Gordian Knot at Last? CEPS Commentary, 18 June, https://www.ceps.eu/system/files/EF_ GreekMacedoniaNameDispute.pdf 
Gligorov, V. (2018): Disagreeing about Alexander the Great is Embarrassing. News \& Opinions, The Vienna Institute for International Economic Studies, 16 February, https://wiiw.ac.at/ disagreeing-about-alexander-the-great-is-embarrassing-n-285.html

Hartwell, C. - Sidlo, K. (2017): Serbia's Cooperation with China, the European Union, Russia and the United States of America. Study for the European Parliament, Directorate-General for External Policies, http://www.europarl.europa.eu/cmsdata/133504/Serbia\%20cooperation\%20 with\%20China,\%20the\%20EU,\%20Russia\%20and\%20the\%20USA.pdf

Hopkins, V. (2017): Indictment Tells Murky Montenegrin Coup Tale. Politico, 23 May, https:// www.politico.eu/article/montenegro-nato-milo-dukanovicmurky-coup-plot/

Hunya, G. - Schwarzhappel, M. (2016): FDI in Central, East and Southeast Europe: Slump Despite Global Upturn. FDI Report 2016, The Vienna Institute for International Economic Studies, https://wiiw.ac.at/slump-despite-global-upturn-dlp-3899.pdf

IMF (2016): Annual Report on Exchange Arrangements and Exchange Restrictions 2016. Washington, D.C., https://www.imf.org/ /media/Files/Publications/AREAER/AREAER_2016_Overview.ashx

IMF (2017a): Albania: 2017 Article IV Consultation - Press Release; Staff Report; and Statement by the Executive Director for Albania', IMF Country Report, No. 17/373, http://www.imf.org/ / media/Files/Publications/CR/2017/cr17373.ashx

IMF (2017b): Former Yugoslav Republic of Macedonia: 2017 Article IV Consultation - Press Release; Staff Report; and Statement by the Executive Director for the Former Yugoslav Republic of Macedonia', IMF Country Report, No. 17/354, http://www.imf.org/ /media/Files/ Publications/CR/2017/cr17354.ashx

IMF (2017c): Republic of Serbia: 2017, Article IV Consultation, Seventh Review Under the Standby Arrangement and Modification of Performance Criteria - Press Release; Staff Report; and Statement by the Executive Director for the Republic of Serbia, IMF Country Report, No. 17/263, http://www.imf.org/ /media/Files/Publications/CR/2017/cr17263.ashx

International Center for Transitional Justice (ICTJ) (2009): Transitional Justice in the Former Yugoslavia, https://www.ictj.org/sites/default/files/ICTJ-FormerYugoslavia-Justice-Facts-2009English.pdf

International Crisis Group (ICG) (2012): Bosnia's Gordian Knot: Constitutional Reform. Europe Brief 68, https://www.crisisgroup.org/file/1377/download?token=-5jv1Ew8

Koen, V. - de Masi, P. (1997): Prices in Transition: Ten Stylized Facts. IMF Working Papers, No. WP/97/158, http://www.imf.org/ /media/Websites/IMF/imported-full-text-pdf/external/pubs/ $\mathrm{ft} / \mathrm{wp} /$ wp97158.ashx

Koettl-Brodmann, J. - de Silva, J. S. - Kupets, O. (2017): Firm Dynamics and Job Creation in the Former Yugoslav Republic of Macedonia. Report Number 112197-MK, World Bank Group, Washington, D.C., http://documents.worldbank.org/curated/en/982121498623703665/ pdf/112197-WP-P133003-PUBLIC-27-6-2017-13-30-59-MKDReportLaborDemandAnalysisFinal.pdf

Koloyanchev, P. - Kusen, I. - Mouzakitis, A. (2018): Untapped Potential: Intra-Regional Trade in the Western Balkans. European Economy - Discussion Paper, No. 080, May, European Commission, Luxembourg, https://ec.europa.eu/info/sites/info/files/economy-finance/dp080 western_balkans.pdf

Kozaric, K.-Begovic, S. (2018): The Banking Sector in the Selected South-Eastern Europe Countries in 2016. In: Garonna, P. - Delneri, F. - Seganti, F. (eds): The Role of Banking, Insurance and Finance. Draft for Discussion. Report for the Trieste Eastern European Investment Forum, 6 June, https://wetransfer.com/downloads/f0641d3ac78705f6e6d8cf552ee530c720180608090845/ad7f ec5ced6dabc48623f92e65166fba20180608090845/605899 
Kynge, J. - Peel, M. (2017): Brussels Rattled as China Reaches out to Eastern Europe. Financial Times, 27 November.

Latinovic, M. - Bogojevic Arsic, V. - Bulajic, M. (2018): Volatility Spillover Effect in the Case of Western Balkans. Acta Oeconomica, 68(1): 79-100.

RFE/RL (2018): EU Calls For 'Calm, Wisdom' as Serbia-Kosovo Tensions Heighten. Radio Free Europe/ Radio Liberty's Balkan Service, 28 March, https://www.rferl.org/a/kosovo-serbsgovernment-walkout-roadblock/29128141.html

Roaf, J. - Atoyan, R. - Joshi, B. - Krogulski, K. - IMF Staff Team (2014): 25 Years of Transition: Post-Communist Europe and the IMF. International Monetary Fund, http://www.imf.org/ external/region/bal/rr/2014/25_years_of_transition.pdf

Sanfey, P. - Milatovic, J. - Kresic, A. (2016): How the Western Balkans can Catch up. EBRD Working Paper, No. 186, http://www.ebrd.com/documents/oce/pdf-working-paper-186.pdf

Stehrer, R. - Holzner, M. (2018): Western Balkan Countries Knocking on EU's Door. News \& Opinions, The Vienna Institute for International Economic Studies, 5 February, https://wiiw. ac.at $/ \mathrm{n}-282 . \mathrm{html}$

Suljagic, E. (2018): Bosnia: Heading Towards Institutional Gridlock? ISPI - Italian Institute for International Political Studies, Commentary, 16 May, https://www.ispionline.it/en/pubblicazione/ bosnia-heading-towards-institutional-gridlock-20532

World Bank (2017): Western Balkans: Revving up the Engines of Growth and Prosperity. Washington, D.C., https://openknowledge.worldbank.org/bitstream/handle/10986/28894/ACS22690.pdf 